\title{
Molecular composition of organic aerosols in central Amazonia: an ultra-high-resolution mass spectrometry study
}

\author{
Ivan Kourtchev ${ }^{1,2}$, Ricardo H. M. Godoi ${ }^{3}$, Sarah Connors ${ }^{1}$, James G. Levine ${ }^{4}$, Alex T. Archibald ${ }^{1,5}$, Ana F. L. Godoi ${ }^{3}$, \\ Sarah L. Paralovo ${ }^{3}$, Cybelli G. G. Barbosa ${ }^{3}$, Rodrigo A. F. Souza ${ }^{6}$, Antonio O. Manzi ${ }^{7}$, Roger Seco $^{8}$, Steve Sjostedt ${ }^{9}$, \\ Jeong-Hoo Park ${ }^{10}$, Alex Guenther ${ }^{8,11}$, Saewung Kim ${ }^{8}$, James Smith ${ }^{12,13}$, Scot T. Martin ${ }^{14,15}$, and Markus Kalberer ${ }^{1}$ \\ ${ }^{1}$ Department of Chemistry, University of Cambridge, Cambridge, CB2 1EW, UK \\ ${ }^{2}$ Department of Chemistry and Environmental Research Institute, University College Cork, Cork, Ireland \\ ${ }^{3}$ Environmental Engineering Department, Federal University of Parana, Curitiba, Brazil \\ ${ }^{4}$ School of Geography Earth \& Environmental Sciences, University of Birmingham, Birmingham, B15 2TT, UK \\ ${ }^{5}$ NCAS climate, University of Cambridge, Cambridge, CB2 1EW, UK \\ ${ }^{6}$ State University of Amazonas, Av. Darcy Vergas, 1200, 69065-020, Manaus-AM, Brazil \\ ${ }^{7}$ Instituto Nacional de Pesquisas da Amazônia (INPA), Clima e Ambiente (CLIAMB), Manaus-AM, Brazil \\ ${ }^{8}$ Department of Earth System Science, University of California, Irvine, CA 92697, USA \\ ${ }^{9}$ NOAA ESRL Chemical Sciences Division, Boulder, CO, USA \\ ${ }^{10}$ Air Quality Forecasting Center, National Institute of Environmental Research, Republic of Korea \\ ${ }^{11}$ Pacific Northwest National Laboratory, Richland, WA, USA \\ ${ }^{12}$ Atmospheric Chemistry Division, National Center for Atmospheric Research, Boulder, CO, USA \\ ${ }^{13}$ Department of Chemistry, University of California, Irvine, CA, USA \\ ${ }^{14}$ School of Engineering and Applied Science, Harvard University, Cambridge, MA 02138, USA \\ ${ }^{15}$ Department of Earth and Planetary Sciences, Harvard University, Cambridge, MA 02138, USA
}

Correspondence to: Ivan Kourtchev (i.kourtchev@ucc.ie) and Markus Kalberer (markus.kalberer@atm.ch.cam.ac.uk)

Received: 14 May 2016 - Published in Atmos. Chem. Phys. Discuss.: 25 May 2016

Revised: 12 August 2016 - Accepted: 31 August 2016 - Published: 23 September 2016

\begin{abstract}
The Amazon Basin plays key role in atmospheric chemistry, biodiversity and climate change. In this study we applied nanoelectrospray (nanoESI) ultra-high-resolution mass spectrometry (UHRMS) for the analysis of the organic fraction of $\mathrm{PM}_{2.5}$ aerosol samples collected during dry and wet seasons at a site in central Amazonia receiving background air masses, biomass burning and urban pollution. Comprehensive mass spectral data evaluation methods (e.g. Kendrick mass defect, Van Krevelen diagrams, carbon oxidation state and aromaticity equivalent) were used to identify compound classes and mass distributions of the detected species. Nitrogen- and/or sulfur-containing organic species contributed up to $60 \%$ of the total identified number of formulae. A large number of molecular formulae in organic aerosol $(\mathrm{OA})$ were attributed to later-generation nitrogenand sulfur-containing oxidation products, suggesting that $\mathrm{OA}$ composition is affected by biomass burning and other, poten-
\end{abstract}

tially anthropogenic, sources. Isoprene-derived organosulfate (IEPOX-OS) was found to be the most dominant ion in most of the analysed samples and strongly followed the concentration trends of the gas-phase anthropogenic tracers confirming its mixed anthropogenic-biogenic origin. The presence of oxidised aromatic and nitro-aromatic compounds in the samples suggested a strong influence from biomass burning especially during the dry period. Aerosol samples from the dry period and under enhanced biomass burning conditions contained a large number of molecules with high carbon oxidation state and an increased number of aromatic compounds compared to that from the wet period. The results of this work demonstrate that the studied site is influenced not only by biogenic emissions from the forest but also by biomass burning and potentially other anthropogenic emissions from the neighbouring urban environments. 


\section{Introduction}

The Amazon Basin plays key role in atmospheric chemistry, biodiversity and climate change (Keller et al., 2009; Andreae et al., 2015). The Amazon rainforest is an important source of biogenic volatile organic compound (BVOC) emissions to the atmosphere (Greenberg et al., 2004; Alves et al., 2016), which give rise to secondary organic aerosol (SOA) through reaction with atmospheric oxidants (i.e. $\mathrm{O}_{3}, \mathrm{OH} \cdot$ and $\mathrm{NO}_{3} \cdot$ ) (e.g. Martin et al., 2010). SOA particles scatter and absorb solar and terrestrial radiation, influence cloud formation, and participate in chemical reactions in the atmosphere and are thus suggested to play an important role in climate change (Andreae and Crutzen, 1997; Haywood and Boucher, 2000; Hallquist et al., 2009; Pöschl et al., 2010). Aerosol optical properties, which govern the ability to absorb solar radiation, strongly depend on SOA composition (Laskin et al., 2015). It has been shown that organic nitrates, nitrooxy organosulfates and organic sulfates may contribute to light absorption by SOA (e.g. Song et al., 2013; Jacobson, 1999; Lu et al., 2011; Laskin et al., 2015). Chemical interactions between anthropogenic and biogenic aerosol precursors can play a significant role in the formation of SOA (Goldstein et al., 2009; Hoyle et al., 2011; Kleinman et al., 2015). For example, anthropogenic nitrogen oxides $\left(\mathrm{NO}_{x}\right)$ and sulfur dioxide $\left(\mathrm{SO}_{2}\right)$ are shown to react with a range of BVOCs, leading to formation of organic nitrates (e.g. Roberts, 1990; Day et al., 2010; Fry et al., 2014), nitroxy organosulfates and organosulfates (Surratt et al., 2008; Budisulistiorini et al., 2015). Much remains to be explored in terms of the molecular diversity of these compounds in the atmosphere.

A comprehensive knowledge of aerosol molecular composition, which in turn leads to a better understanding of aerosol sources, is required for the development of effective air pollution mitigation strategies. However, identification of the organic aerosol composition remains a major analytical challenge (Nozière et al., 2015). Organic aerosol is composed of thousands of organic compounds, which cover a wide range of physical and chemical properties (Goldstein and Galbally, 2007), making it difficult to find a single analytical technique for a detailed chemical analysis at the molecular level. Methods based on ultra-high-resolution mass spectrometry (UHRMS) have shown great potential in solving this longstanding problem. UHR mass spectrometers (e.g. Fourier transform ion cyclotron resonance mass spectrometer and Orbitrap mass spectrometer) have mass resolution power that is at least 1 order of magnitude higher $(\geq 100000)$ than conventional MS and high mass accuracy $(<5 \mathrm{ppm})$ and thus, when coupled with soft ionisation techniques (e.g. electrospray ionisation, ESI), can provide a detailed molecular composition of the organic aerosol (Nizkorodov et al., 2011; Nozière et al., 2015). Direct infusion ESIUHRMS has been applied successfully for the analysis of aerosol samples from remote (e.g. boreal forest in Finland, Pico Island of the Azores archipelago), rural (e.g. Millbrook,
USA; Harcum, USA; K-Puszta, Hungary) and urban (e.g. Cambridge, UK; Birmingham, UK; Cork, Ireland; Shanghai, China; and Los Angeles, USA) locations (Wozniak et al., 2008; Schmitt-Kopplin et al., 2010; Kourtchev et al., 2013, 2014; Tao et al., 2014; Dzepina et al., 2015). UHRMS has proven to be extremely useful in assessing chemical properties of the SOA.

The aim of this study was to investigate the detailed molecular composition of organic aerosol from a site that received air masses from a wide range of origins, including the background atmosphere of Amazonia, biomass burning and urban pollution plumes. The measurements were performed as a part of the Observations and Modeling of the Green Ocean Amazon (GoAmazon2014/5) campaign (Martin et al., 2016). The location of the research site where aerosol was collected for this study is $\sim 69 \mathrm{~km}$ downwind of Manaus (population 2 million), intersecting background and polluted air with day-to-day variability in the position of the Manaus plume. The study designed served as a laboratory for investigating anthropogenic perturbations to biogenic processes and atmospheric chemistry.

\section{Methods}

\subsection{Sampling site}

Aerosol sampling was conducted at site "T3" of GoAmazon $2014 / 5$ located at $-3.2133^{\circ}$ and $-60.5987^{\circ}$. The T3 site is located in the pasture area, $\sim 2.5 \mathrm{~km}$ from the rainforest. The air masses arriving to the sampling site often passed over the single large city (Manaus) in the region. Detailed descriptions of the site and instrumentation are provided in Martin et al. (2016).

$\mathrm{PM}_{2.5}$ aerosol samples were collected on $47 \mathrm{~mm}$ polycarbonate filters (Nuclepore) using a Harvard impactor (Air Diagnostics, Harrison, ME, USA) with flow rate of $10 \mathrm{~L} \mathrm{~min}^{-1}$ from 5 to 26 March 2014 and 5 September to 4 October 2014, which were during intensive observation periods 1 and 2 (IOP1 and IOP2) of GoAmazon2014/5, respectively, corresponding to the traditional periods of wet and dry seasons of Amazonia. The sampling durations are shown in Table S1 in the Supplement. The airflow through the sampler was approximately $10 \mathrm{~L} \mathrm{~min}^{-1}$. After collection, the aerosol samples were transferred into Petri dishes and stored in the freezer at $-4^{\circ} \mathrm{C}$ until analysis.

\subsection{Aerosol sample analysis}

Fifteen samples, 5 from IOP2 and 10 from IOP1, were extracted and analysed using a procedure described elsewhere (Kourtchev et al., 2014, 2015). Depending on the aerosol loading of the analysed samples, a part (half to whole) of the filter was extracted in methanol (Optima TM LC/MS grade, Fisher Scientific) in a chilled ice slurry, filtered through a Teflon filter $(0.2 \mu \mathrm{m}$, ISODiscTM, Supelco) and reduced by 
volume using a nitrogen line to achieve approximately $0.3 \mu \mathrm{g}$ of aerosol per microlitre of methanol. Several samples with the highest aerosol loading were divided into two parts for both direct infusion and LC/MS analyses, while the samples with the lowest loading were only analysed using direct infusion analysis. The LC/MS portion was further evaporated to $20 \mu \mathrm{L}$ and diluted to $100 \mu \mathrm{L}$ by aqueous solution of formic acid $(0.1 \%)$. The final extracts were analysed as described in Kourtchev et al. (2013) using a high-resolution LTQ Orbitrap Velos mass spectrometer (Thermo Fisher, Bremen, Germany) equipped with an ESI and a TriVersa NanoMate robotic nanoflow chip-based ESI (Advion Biosciences, Ithaca NY, USA) source. The Orbitrap MS was calibrated using an Ultramark 1621 solution (Sigma-Aldrich, UK). The mass accuracy of the instrument was below $1 \mathrm{ppm}$. The instrument mass resolution was 100000 at $m / z$ 400. The ion transmission settings were optimised using a mixture of camphor sulfonic acid $\left(20 \mathrm{ng} \mu \mathrm{L}^{-1}\right)$, glutaric acid $\left(30 \mathrm{ng} \mu \mathrm{L}^{-1}\right)$,

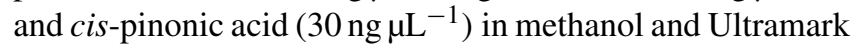
1621 solution.

\subsection{Direct infusion UHRMS analysis}

The ionisation voltage and back pressure of the nanoESI direct infusion source were set at $-1.4 \mathrm{kV}$ and $0.8 \mathrm{psi}$, respectively. The inlet temperature was $200^{\circ} \mathrm{C}$ and the sample flow rate was approximately $200-300 \mathrm{~nL} \mathrm{~min}^{-1}$. The negative ionisation mass spectra were collected in three replicates at two mass ranges $(m / z, 100-650$ and $m / z 150-900)$ and processed using Xcalibur 3.1 software (Thermo Fisher Scientific Inc.). Similar to our preceding studies (Kourtchev et al., 2015), the average percentage of common peaks between analytical replicates was $\sim 80 \%$. This is also in agreement with literature reports for similar data analysis (Sleighter et al., 2012). The identification of IEPOX organosulfates was performed by comparing MS fragmentation patterns and chromatographic elution time with a synthesised IEPOX-OS standard which was provided by Dr Surratt from the University of North Carolina. It must be noted that, due to competitive ionisation of analytes in the direct infusion ESI analysis of the samples with a very complex matrix (i.e. aerosol extracts), the ion intensities do not directly reflect the concentration of the molecules in the sample (Oss et al., 2010); therefore, data shown in this work are semi-quantitative.

\subsection{LC/MS analysis}

LC/MS ESI parameters were as follows: spray voltage, $-3.6 \mathrm{kV}$; capillary temperature, $300^{\circ} \mathrm{C}$; sheath gas flow, 10 arbitrary units, auxiliary gas flow, 10 arbitrary units; sweep gas flow rate, 5 arbitrary units; and S-lens RF level, $58 \%$. LC/(-)ESI-MS analysis was performed using an Accela system (Thermo Scientific, San Jose, USA) coupled with LTQ Orbitrap Velos MS and a T3 Atlantis C18 column $(3 \mu \mathrm{m}$; $2.1 \times 150 \mathrm{~mm}$; Waters, Milford, USA). The sample extracts were injected at a flow rate of $200 \mu \mathrm{L} \mathrm{min}{ }^{-1}$. The mobile phases consisted of $0.1 \%$ formic acid $(v / v)$ (A) and methanol (B). The applied gradient was as follows: $0-3 \mathrm{~min}$ $3 \% \mathrm{~B}, 3-25 \mathrm{~min}$ from 3 to $50 \% \mathrm{~B}$ (linear), 25-43 min from 50 to $90 \%$ B (linear), 43-48 min from 90 to $3 \%$ B (linear), and then kept for $12 \mathrm{~min}$ at $3 \% \mathrm{~B}$. The collision-induced dissociation (CID) settings for MS/MS analysis are reported in Kourtchev et al. (2015).

\subsection{High-resolution MS data analysis}

The direct infusion data analysis was performed using procedures described in detail by Kourtchev et al. (2013). The calibration (as described in Kourtchev et al., 2013) and ion transmission checks that include monitoring of ion signal intensity were routinely performed. Briefly, for each sample analysis, 60-90 mass spectral scans were averaged into one mass spectrum. Molecular formulae assignments were made using Xcalibur 3.1 software using the following constraints: ${ }^{12} \mathrm{C} \leq 100,{ }^{13} \mathrm{C} \leq 1,{ }^{1} \mathrm{H} \leq 200,{ }^{16} \mathrm{O} \leq 50,{ }^{14} \mathrm{~N} \leq 5,{ }^{32} \mathrm{~S} \leq 2$, ${ }^{34} \mathrm{~S} \leq 1$. The data processing was performed using a Mathematica 8.0 (Wolfram Research Inc., UK) code developed in-house that utilises a number of additional constraints described in previous studies (Kourtchev et al., 2013, 2015). Only ions that appeared in all three replicates were kept for evaluation. The background spectra obtained from the procedural blanks were also processed using the rules mentioned above. The formulae lists of the background spectra were subtracted from those of the ambient (or chamber) sample and only formulae with a sample/blank peak intensity ratio $\geq 10$ were retained.

The Kendrick mass defect (KMD) is calculated from the difference between the nominal mass of the molecule and the exact KM (Kendrick, 1963). Kendrick mass of the $\mathrm{CH}_{2}$ unit is calculated by renormalising the exact IUPAC mass of $\mathrm{CH}_{2}$ (14.01565) to 14.00000 .

\subsection{Benzene and isoprene measurements}

For benzene and isoprene analysis we used a high-resolution selective-reagent-ionisation proton transfer reaction time-offlight mass spectrometer (SRI-PTR-TOF-MS 8000, Ionicon Analytik, Austria). The data reduction process used and a description of the PTR-TOF-MS instrument are provided elsewhere (Graus et al., 2010; Müller et al., 2013). Background of the instrument was measured regularly by passing ambient air through a platinum catalyst heated to $380^{\circ} \mathrm{C}$. Sensitivity calibrations were performed by dynamic dilution of VOCs using several multi-component gas standards (Apel Riemer Environmental Inc., Scott-Marrin, and Air Liquide, USA). The calibration cylinders contained acetaldehyde, acetone, benzene, isoprene, $\alpha$-pinene, toluene and trichlorobenzene, among other species During IOP1, the instrument was operated with the $\mathrm{H}_{3} \mathrm{O}^{+}$reagent ion and at a drift tube pressure of $2.3 \mathrm{mbar}$, voltage of $600 \mathrm{~V}$, and temperature of $60^{\circ} \mathrm{C}$, 
corresponding to a field density ratio $E / N$ ratio of $130 \mathrm{Td}$ ( $E$ being the electric field strength and $N$ the gas number density; $1 \mathrm{Td}=10^{-17} \mathrm{~V} \mathrm{~cm}^{-2}$ ). During IOP2, the reagent ion was $\mathrm{NO}^{+}$and the drift tube settings were $2.3 \mathrm{mbar}, 350 \mathrm{~V}$, and $60^{\circ} \mathrm{C}$, resulting in an $E / N$ ratio of $76 \mathrm{Td}$. The sampling was done with $1 \mathrm{~min}$ time resolution and the instrument detection limit for benzene and isoprene were below 0.02 and 0.04 ppbv, respectively.

\subsection{Air mass history analysis}

Air mass history analysis was done for the sampling period using the Numerical Atmospheric-dispersion Modelling Environment (NAME) model, developed by the UK Met Office (Maryon et al., 1991). NAME is a Lagrangian model in which particles are released into 3-D wind fields from the operational output of the UK Met Office Unified Model meteorology data (Davies et al., 2005). These winds have a horizontal resolution of $17 \mathrm{~km}$ and 70 vertical levels, which reach $\sim 80 \mathrm{~km}$. In addition, a random walk technique was used to model the effects of turbulence on the trajectories (Ryall and Maryon, 1998). To allow the calculation of air mass history for the average sampling time (which varied between samples, 24,36 or $48 \mathrm{~h}$ ), $10^{4}$ particles per hour were released continuously from the $\mathrm{T} 3$ site. The trajectories travelled back in time for 3 days with the position of the particles in the lowest $100 \mathrm{~m}$ of the model atmosphere recorded every $15 \mathrm{~min}$. The particle mass below $100 \mathrm{~m}$ was integrated over the $72 \mathrm{~h}$ travel time. The air mass history ("footprints") for the periods of the analysed filters are shown in Fig. S1 in the Supplement. The majority of the 3-day air mass footprints originated from the east, although wind direction showed variability nearer to the sampling site on some occasions, e.g. sample MP1417 (Fig. S1). Almost all air masses pass over Manaus and therefore highlight this city as a potential source. Some air masses also pass over Manacapuru, but this is rare and the corresponding time-integrated concentrations are lower than the equivalent Manaus values.

\section{Results and discussion}

Figure 1 shows mass spectra from two typical samples collected during IOP1 and IOP2. The majority of the ions were associated with molecules below $500 \mathrm{Da}$, although the measured mass goes up to $900 \mathrm{Da}$. Although ESI is a "soft" ionisation technique resulting in minimal fragmentation, we cannot exclude the possibility that some of the detected ions correspond to fragments, also in light of the many relative fragile compounds (e.g. thermally labile compounds) that constitute OA. The largest group of identified molecular formulae in all samples were attributed to molecules containing $\mathrm{CHO}$ atoms only $(1051 \pm 141$ formulae during IOP2 and $820 \pm 139$ during IOP1), followed by CHON (537 \pm 71 during IOP2 and $329 \pm 71$ during IOP1), CHOS $(183 \pm 34$ during IOP2 and
$137 \pm 31$ during IOP1) and CHONS (37 \pm 11 during IOP2 and $28 \pm 10$ during IOP1) (Fig. 2). The number of molecular formulae containing $\mathrm{CHO}$ and $\mathrm{CHON}$ subgroups increased by $\sim 20 \%$ from IOP1 to IOP2; however, a rather insignificant increase was observed for CHOS and CHONS subgroups. The Student's $t$ test showed that the observed difference for CHO ( $p=0.0092)$ and CHON ( $p=0.00007)$ subgroups between two seasons is statistically significant. This is consistent with the observed increase in odd reactive nitrogen species $\left(\mathrm{NO}_{y}\right)$ from IOP1 to IOP2 (Table S1). Organic nitrates are believed to form in polluted air through reaction with nitrogen oxides during daytime and from reaction of $\mathrm{NO}_{3}$ • with BVOCs during nighttime (Day et al., 2010; Ayres et al., 2015). The average concentration of $\mathrm{NO}_{y}$ during IOP1 was found to be on almost 2 times higher, which is possibly reflected in the increased number of organonitrates in the aerosol samples from IOP2. Moreover, the increase in the number of organonitrates during IOP2 is consistent with recent studies which demonstrated that organonitrates groups in aerosol particles may hydrolyse under high-RH conditions (Liu et al., 2012). In this respect, while night-time maximum RH during both filter sampling periods was very similar ( $~ 90 \%)$, daytime RH during IOP1 was higher ( $89 \%)$ compared to that from IOP2 (66\%) (Fig. S2).

Carbon oxidation state $\left(\mathrm{OS}_{\mathrm{C}}\right)$ introduced by Kroll et al. (2011) can be used to describe the composition of a complex mixture of organics undergoing oxidation processes. $\mathrm{OS}_{\mathrm{C}}$ was calculated for each molecular formula identified in the mass spectra using the following equation:

$\mathrm{OS}_{\mathrm{C}}=-\sum_{i} \mathrm{OS}_{i} \frac{n_{i}}{n_{\mathrm{C}}}$

where $\mathrm{OS}_{i}$ is the oxidation state associated with element $i$ and $n_{i} / n_{\mathrm{C}}$ is the molar ratio of element $i$ to carbon within the molecule (Kroll et al., 2011).

Figure 3 shows overlaid $\mathrm{OS}_{\mathrm{C}}$ plots for two samples from IOP1 and IOP2. Consistent with previous studies, the majority of molecules in the sampled organic aerosol had $\mathrm{OS}_{\mathrm{C}}$ between -1.5 and +1 with up to $30(\mathrm{nC})$ carbon atoms throughout the selected mass range $(m / z 100-650)$ (Kroll et al., 2011, and the references therein). The molecules with $\mathrm{OS}_{\mathrm{C}}$ between -1 and +1 with 13 or fewer carbon atoms $(\mathrm{nC})$ are suggested to be associated with semivolatile and lowvolatility oxidised organic aerosol (SV-OOA and LV-OOA) produced by multistep oxidation reactions. The molecules with $\mathrm{OS}_{\mathrm{C}}$ between -0.5 and -1.5 with seven or more carbon atoms are associated with primary biomass burning organic aerosol (BBOA) directly emitted into the atmosphere (Kroll et al., 2011). The cluster of molecules with OS $_{C}$ between -1 and -1.5 and $\mathrm{nC}$ fewer than 10 could be possibly associated with $\mathrm{OH}$ radical oxidation products of isoprene (Kourtchev et al., 2015), which is an abundant VOC in Amazon rainforest (Rasmussen and Khalil, 1988; Chen et al., 2015). The isoprene daytime average was above $1.5 \mathrm{ppbv}$ during both seasons, with hourly campaign averages reach- 


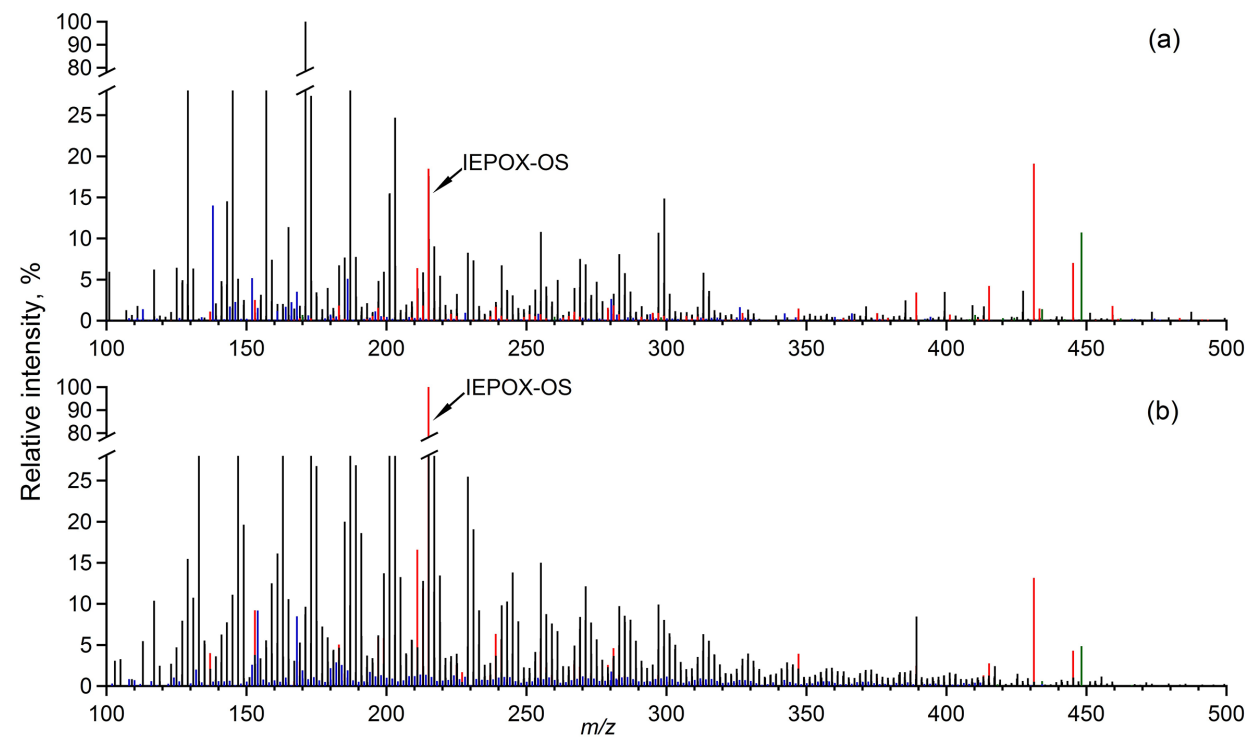

Figure 1. (-)-nanoESI-UHRMS of the representative PM2.5 samples during (a) IOP1 and (b) IOP2. The line colours in the mass spectra correspond to the $\mathrm{CHO}$ (black), blue ( $\mathrm{CHON}$ ), $\mathrm{CHOS}$ (red) and CHONS (green) formulae assignments. The relative-intensity axis was split to make a large number of ions with low intensities visible.

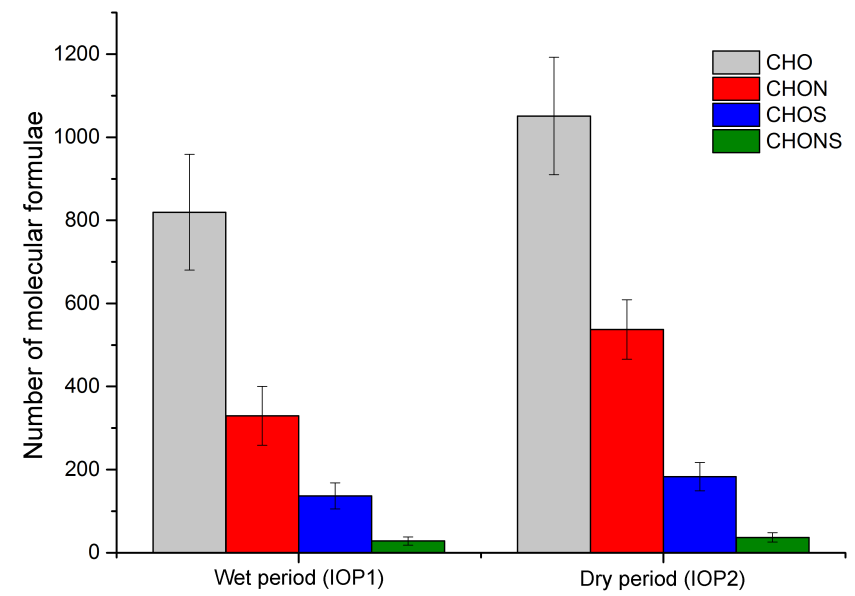

Figure 2. Average number of molecular formulae during IOP1 and IOP2. Standard deviation bars show variations between samples within individual season.

ing up to 2.3 and $3.4 \mathrm{ppbv}$ for IOP1 and IOP2, respectively. In general, aerosol samples from IOP1 contained fewer oxidised molecules compared to those from IOP2. Wet deposition of aged or processed aerosol during the wet (i.e. IOP 2) sampling period cannot be the only reason for the observed differences in $\mathrm{OS}_{\mathrm{C}}$. It has been shown that different oxidation regimes to generate SOA (e.g. OH radical vs. ozonolysis) can result in significantly different $\mathrm{OS}_{\mathrm{C}}$ of $\mathrm{SOA}$ (Kourtchev et al., 2015). For example, the SOA component from the $\mathrm{OH}$ radical-initiated oxidation of $\alpha$-pinene as well as BVOC mixtures had a molecular composition with higher
$\mathrm{OS}_{\mathrm{C}}$ throughout the entire molecular mass range compared to that obtained from the ozonolysis reaction (Kourtchev et al., 2015).

Figure 4 shows the distribution of ion signal intensities for selected tentatively identified tracer compounds for anthropogenic, biogenic and mixed sources in all 15 samples. The structural or isomeric information is not directly obtained from the direct infusion analysis; therefore, the identification of the tracer compounds was achieved by comparing MS/MS fragmentation patterns from authentic standards and published literature. The tracer compounds include anhydrosugars, structural isomers with a molecular formula of $\mathrm{C}_{6} \mathrm{H}_{10} \mathrm{O}_{5}$ at $m / z 161.0456$ corresponding to levoglucosan, mannosan, galactosan and 1,6-anhydro- $\beta$ - $D$-glucofuranose, which are regarded as marker compounds for biomass burning (Simoneit et al., 1999; Pashynska et al., 2002; Kourtchev et al., 2011). Nitrocatechols, with a molecular formula of $\mathrm{C}_{6} \mathrm{H}_{5} \mathrm{NO}_{4}(m / z$ 154.01458), are attributed to mixed anthropogenic sources, e.g. biomass and vehicular emissions, and methyl-nitrocatechols $\left(\mathrm{C}_{7} \mathrm{H}_{7} \mathrm{NO}_{4}, m / z\right.$ 168.03023) are important markers for biomass burning OA, formed from $m$ cresol emitted during biomass burning (Iinuma et al., 2010) as well as diesel exhaust. 3-Methyl-1,2,3-butanetricarboxylic acid (3-MBTCA), with a molecular formula of $\mathrm{C}_{8} \mathrm{H}_{12} \mathrm{O}_{6}$ at $m / z 203.05611$, is an $\mathrm{OH}$ radical-initiated oxidation product of $\alpha$ - and $\beta$-pinene (Szmigielski et al., 2007), and regarded as a tracer for processed or biogenic SOA. Finally, isoprene epoxydiol organosulfate ester (IEPOX-OS), with a molecular formula of $\mathrm{C}_{5} \mathrm{H}_{12} \mathrm{O}_{7} \mathrm{~S}$ at $m / z 215.0231$, has been suggested to be formed through reactions between $\mathrm{SO}_{x}$ and isoprene oxidation products (Pye et al., 2013; Budisulistior- 


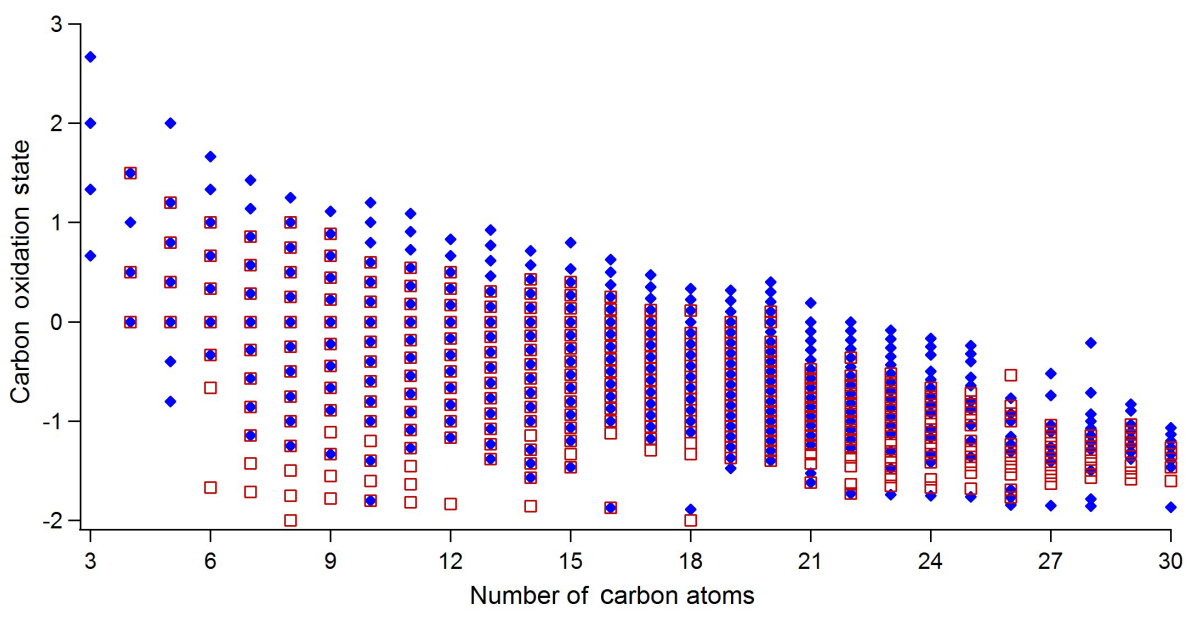

Figure 3. Carbon oxidation state plot for CHO-containing formulae in organic aerosol from IOP1 (red squares) and IOP2 (blue diamonds).

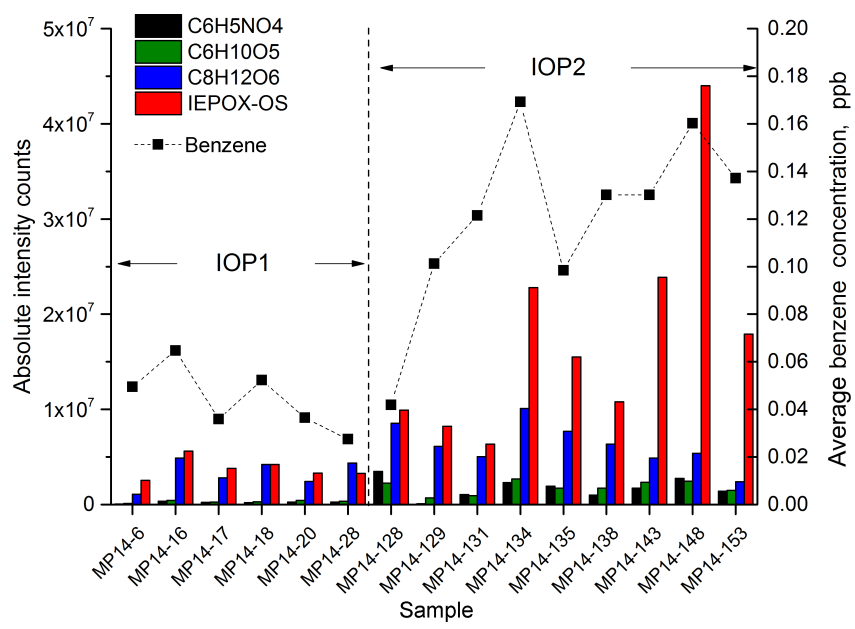

Figure 4. Ion intensity distributions (left axis) of selected tentatively identified markers in individual samples using UHRMS analysis and averaged benzene concentration (right axis) from PTRTOF-MS analysis. Benzene concentration was averaged for the aerosol filter sampling intervals. The UHRMS data were corrected for organic carbon load in each individual filter sample (see Methods section).

ini et al., 2015) and thus can be used to observe the extent of $\mathrm{SO}_{2}$ ageing effects on the biogenic SOA. Direct infusion analysis suffers from competitive ionisation in the complex matrices and thus comparing ion intensities across samples must be done with caution. Moreover, other compounds with similar molecular composition present in the aerosol matrix may also contribute to the ion signal intensities of the abovediscussed compounds. All selected tracers showed very similar variations with benzene concentration that was measured in the gas phase using PTR-MS (Fig. 3). Benzene, generally regarded as an anthropogenic species, has various sources, including industrial solvent production, vehicular emissions and biomass burning (Hsieh et al., 1999; Seco et al., 2013; Friedli et al., 2001). Recent studies have indicated that vegetation (leaves, flowers, and phytoplankton) emits a wide variety of benzenoid compounds to the atmosphere at substantial rates (Misztal et al., 2015). However, considering that benzene concentration correlated very well with another anthropogenic tracer $\mathrm{CO}\left(R^{2}=0.77\right.$, Fig. S3 $)$ during IOP1 and IOP2, it is likely that the observed benzene concentrations were mainly due to anthropogenic emissions. During the sampling period, irrespective of the season, air masses passed over the large city Manaus and small municipalities located near the T3 site (Fig. S1). It must be noted that, due to rather low sampling resolution time ( $\geq 24 \mathrm{~h}$ ), the molecular composition of all analysed samples is likely to be influenced by clean air masses and anthropogenic plumes from these urban locations which usually last only a few hours per day, and thus individual urban plume events cannot be identified with the data analysed here. In Manaus natural gas is mainly used for heating and cooking and therefore the contribution from these activities to biomass burning OA at our site is highly unlikely. During IOP1 much lower incidents of forest fires were observed compared to that during IOP2 (Martin et al., 2016). For example, the number of forest fires in the radius of $200 \mathrm{~km}$ from the sampling site varied between 0 and 340 fires (http://www.dpi.inpe.br/proarco/bdqueimadas/). This is reflected in the ion signal intensities of the particle-phase biomass burning markers, i.e. anhydrosugars $\left(\mathrm{C}_{6} \mathrm{H}_{10} \mathrm{O}_{5}\right)$ and nitrocatechols $\left(\mathrm{C}_{6} \mathrm{H}_{5} \mathrm{NO}_{4}\right)$ and gas-phase benzene concentrations, which were significantly lower during IOP1 compared to that from IOP2, when on average more fires are observed.

It should be noted that ion signal intensities for anhydrosugars $\left(\mathrm{C}_{6} \mathrm{H}_{10} \mathrm{O}_{5}\right)$ and nitrocatechols $\left(\mathrm{C}_{6} \mathrm{H}_{5} \mathrm{NO}_{4}\right)$ showed a very good correlation $\left(R^{2}>0.7\right)$, suggesting that nitrocatechols, observed at the sampling site, are mainly associated with biomass burning sources. The highest ion signal in- 
tensities of these tracer compounds were observed during two periods: 7-9 September 2014 (sample MP14-128) and 27-28 September 2014 (sample MP14-148) with the latter one coinciding with highest incident of fires (340 fires). Although during 7-9 September (sample MP14-128) a significantly lower number (22 fires) of fires was observed compared to the period of 27-28 September 2014, lower wind speed occurring during 7-9 September suggests that a high intensity of the biomass burning markers could be due to the biomass burning emissions from nearby sources. Between the T3 sampling site and Manaus (about $20 \mathrm{~km}$ east of the site), there are a number of small brick factories, which use wood to fire the kilns (Martin et al., 2016) and are thus an additional local wood-burning source besides the forest and pasture fires.

Interestingly the sample MP14-148 had the highest ion intensity corresponding to IEPOX-OS (Fig. 4), which also coincided with the strong increase in the ion intensity at $m / z 96.95987$ corresponding to $\left[\mathrm{HSO}_{4}\right]^{-}$. This is consistent with the organosulfate formation mechanism through reactive uptake of isoprene epoxydiols (IEPOX) in the presence of acidic sulfate seed (Surratt et al., 2010; Lin et al., 2012, 2013). A similar relationship between sulfate and organosulfates concentrations has been observed previously in field studies in the southeastern US (Surratt et al., 2007, 2008, 2010; Lin et al., 2012, 2013). This is also in agreement with previous studies from the Amazon, where the highest levels of 2-methyltetrols were observed during the dry period, which was characterised by biomass burning (and higher particle concentrations of sulfuric acid) (Claeys et al., 2010). Considering that Claeys et al. (2010) employed an alternative GC/MS procedure with prior trimethylsilylation, 2-methyltetrol sulfates were converted to 2-methyltetrols and not detectable as separate organosulfate compounds. It should be noted that the 27-28 September period (sample MP14-148) was marked by a very strong increase in the CO concentration (Fig. S4). In mid-latitude environments it has been suggested that the production of anthropogenic SOA in an air mass, as it travels from an urban source region, can be estimated by using a relatively inert pollution tracer, such as CO occurring in the air mass (De Gouw et al., 2005; Hoyle et al., 2011). At the T3 sampling site, the highest CO concentrations are observed in air masses affected by biomass burning. Therefore, it is possible that organic aerosol in the sample MP14-148 has experienced the highest contribution from biomass burning as well as other anthropogenic activities.

To investigate the influence of anthropogenic activities (i.e. biomass burning) on a detailed molecular composition of organic aerosol at the T3 site, we compared samples from the periods with the lowest (9 fires), moderately high (254 fires) and the highest (340 fires) incidents of fires occurring within $200 \mathrm{~km}$ around the site.

Figure $5 \mathrm{a}-\mathrm{c}$ show $\mathrm{H} / \mathrm{C}$ ratios of $\mathrm{CHO}-$ containing formulae as a function of their molecular mass and double- bond equivalent (DBE), which shows a degree of unsaturation of the molecule, for a sample with the lowest (a) moderately high (b) and highest incidents (c) of fires. One of the obvious differences between these samples is the abundance of ions with low $\mathrm{H} / \mathrm{C}$ ratios $(<1)$. The majority of these ions have a DBE value above 7 , indicating that they likely correspond to oxidised aromatic compounds, which are mainly of anthropogenic origin (Kourtchev et al., 2014; Tong et al., 2016). For example, the smallest polycyclic aromatic hydrocarbon ( $\mathrm{PAH})$, naphthalene, with a molecular formulae of $\mathrm{C}_{10} \mathrm{H}_{8}$, has $\mathrm{H} / \mathrm{C}=0.8$ and $\mathrm{DBE}=7$. The number of $\mathrm{CHO}$-containing formulae with high DBE equivalent and low $\mathrm{H} / \mathrm{C}$ increased dramatically during the days with moderately high and high incidents of fires (Fig. 5a-c), suggesting that they are mainly associated with biomass burning. The largest grey circles in Fig. 5ac correspond to the ions at $m / z 133.01425$ (with a neutral molecular formula of $\left.\mathrm{C}_{4} \mathrm{H}_{6} \mathrm{O}_{5}\right), \mathrm{m} / z 187.0612\left(\mathrm{C}_{8} \mathrm{H}_{12} \mathrm{O}_{5}\right)$, $m / z 201.07685\left(\mathrm{C}_{9} \mathrm{H}_{14} \mathrm{O}_{5}\right), m / z 203.05611\left(\mathrm{C}_{8} \mathrm{H}_{12} \mathrm{O}_{6}\right)$, and $m / z 215.05611\left(\mathrm{C}_{9} \mathrm{H}_{12} \mathrm{O}_{6}\right)$ with $\mathrm{DBE}<6$.

Recent studies have indicated that different families of compounds with heteroatoms (e.g. O, S) overlap in terms of DBE and thus may not accurately indicate the level of unsaturation of organic compounds. For example, the divalent atoms, such as oxygen and sulfur, do not influence the value of DBE, yet they may contribute to the potential double bonds of that molecule (Reemtsma, 2009; Yassine et al., 2014). Yassine et al. (2014) suggested using aromaticity equivalent $\left(X_{\mathrm{c}}\right)$ to improve the identification and characterisation of aromatic and condensed aromatic compounds in water-soluble organic carbon. The aromaticity equivalent can be calculated as follows:

$X_{\mathrm{c}}=\frac{3\left(\mathrm{DBE}-\left(m N_{\mathrm{O}}+n N_{\mathrm{S}}\right)\right)-2}{\mathrm{DBE}-\left(m N_{\mathrm{O}}+n N_{\mathrm{S}}\right)}$,

where " $m$ " and " $n$ " correspond to a fraction of oxygen and sulfur atoms involved in $\pi$-bond structures of a compound which varies depending on the compound class. For example, carboxylic acids, esters, and nitro functional groups have $m=n=0.5$. For compounds containing functional groups such as aldehydes, ketones, nitroso, cyanate, alcohol, or ethers " $m$ " and " $n$ " are 1 or 0 . Considering that ESI, in negative mode, is most sensitive to compounds containing carboxylic groups we therefore used $m=n=0.5$ for the calculation of the $X_{\mathrm{c}}$. For molecular formulae with an odd number of oxygen or sulfur, the sum $\left(m N_{\mathrm{O}}+n N_{\mathrm{S}}\right)$ in Eq. (2) was rounded down to the closest integer as detailed in Yassine et al. (2014). The authors proposed that aromaticity equivalent with $X_{\mathrm{c}} \geq 2.50$ and $X_{\mathrm{c}} \geq 2.71$ as unambiguous minimum criteria for the presence of aromatics and condensed aromatics.

Expressing our data using aromaticity equivalents confirmed that the increase in the number of molecules with high DBE from the sample with the lowest to the highest incidents of fires was due to the increase in the number of 


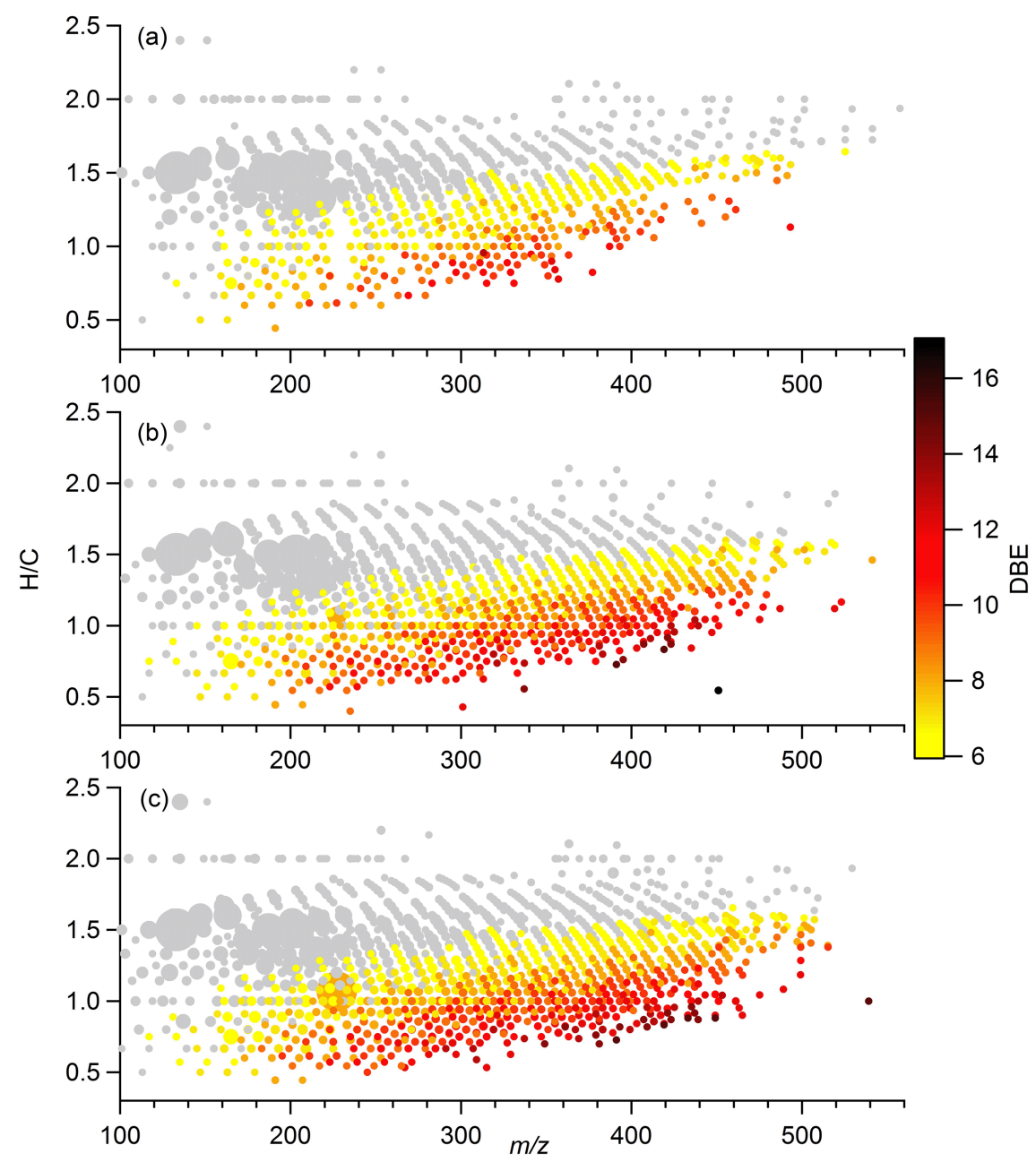

Figure 5. H / C vs. $m / z$ plot for CHO-containing formulae in the samples from the periods with (a) low, (b) moderately high and (c) very high incidents of fires. The marker size reflects relative ion abundance in the sample. The colour code shows double-bond equivalent (DBE) in the individual molecular formula. Molecular formulae with $\mathrm{DBE}<6$ are shown as grey markers. The largest grey circles correspond to the ions at $m / z 133.01425$ (with a neutral molecular formula of $\left.\mathrm{C}_{4} \mathrm{H}_{6} \mathrm{O}_{5}\right), m / z 187.0612\left(\mathrm{C}_{8} \mathrm{H}_{12} \mathrm{O}_{5}\right), m / z 201.07685\left(\mathrm{C}_{9} \mathrm{H}_{14} \mathrm{O}_{5}\right), m / z 203.05611$ $\left(\mathrm{C}_{8} \mathrm{H}_{12} \mathrm{O}_{6}\right)$, and $m / z 215.05611\left(\mathrm{C}_{9} \mathrm{H}_{12} \mathrm{O}_{6}\right)$.

aromatic and condensed aromatic compounds in the aerosol samples (Fig. S5). Considering the Yassine et al. (2014) assignment criteria for the aromatic-reach matrices, the highest number of the aromatic compounds in the Amazon samples was observed for formulae with a benzene core structure $\left(X_{\mathrm{c}}=2.50\right)$, followed by formulae with a pyrene core structure $\left(X_{\mathrm{c}}=2.83\right)$, an ovalene core structure $\left(X_{\mathrm{c}}=2.92\right)$, and highly condensed aromatic structures or highly unsaturated compounds $\left(X_{\mathrm{c}}>2.93\right)$. The largest grey circles in Fig. S5a correspond to the ions at $m / z 187.11357$ with a neutral molecular formula of $\mathrm{C}_{9} \mathrm{H}_{17} \mathrm{NO}_{3}$ and $m / z 281.26459$ with a neutral molecular formula of $\mathrm{C}_{18} \mathrm{H}_{35} \mathrm{NO}$. The largest grey circles in Fig. S5b and c correspond to the ions at $m / z 154.0146, m / z 168.03023$ and $m / z 152.03532$ with neutral molecular formulae of $\mathrm{C}_{6} \mathrm{H}_{5} \mathrm{NO}_{4}, \mathrm{C}_{7} \mathrm{H}_{7} \mathrm{NO}_{4}$ and $\mathrm{C}_{7} \mathrm{H}_{7} \mathrm{NO}_{3}$, respectively.
Interestingly, a similar trend was observed for the molecules containing CHON subgroups (Fig. S6). A number of CHON molecules with low $\mathrm{H} / \mathrm{C}(<1)$ and high DBE ( $\geq 5$ ) almost doubled from the days with 9 to 340 fires (Fig. S7). Nitro-aromatic compounds such as nitrophenols $(\mathrm{DBE}=5)$ and $\mathrm{N}$-heterocyclic compounds, including 4nitrocatechol and isomeric methyl-nitrocatechols, are often observed in the OA from biomass burning sources (Kitanovski et al., 2012a, b; Iinuma et al., 2010) and have been suggested to be potential contributors to light absorption by brown carbon (Laskin et al., 2015). It is worth mentioning that aerosol samples affected by biomass burning contained another interesting ion at $m / z 182.04588$ with a neutral molecular formula of $\mathrm{C}_{8} \mathrm{H}_{9} \mathrm{NO}_{4}$, possibly corresponding to other biomass burning OA markers, i.e. isomeric dimethylnitrocatechols (Kahnt et al., 2013). The differences in the in- 


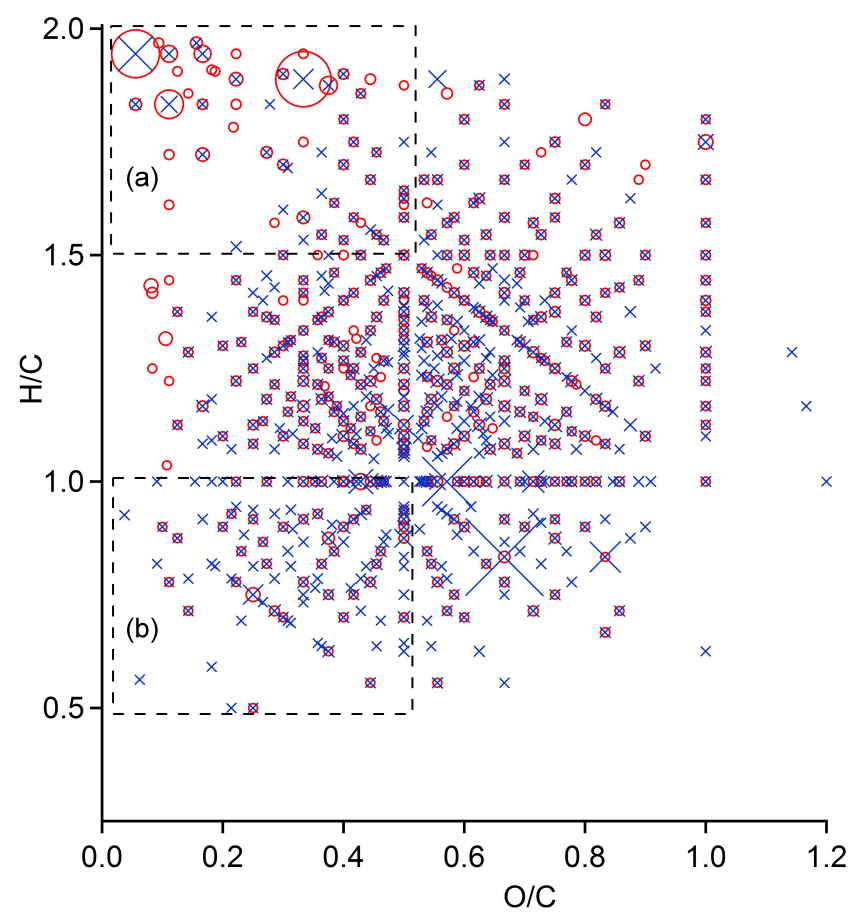

Figure 6. Overlaid Van Krevelen diagrams for CHON-containing formulae in the samples from the periods with low (red markers) and very high incidents (blue markers) of fires. The marker areas reflect relative ion abundance in the sample. Areas " $A$ " and " $B$ " indicate differences in the number of ions tentatively attributed to aliphatic and aromatic species, respectively.

creased number of nitro-aromatic compounds in aerosol samples affected by biomass burning are also apparent in overlaid Van Krevelen diagrams (Fig. 6), which show H / C and $\mathrm{O} / \mathrm{C}$ ratios for each formula in a sample. Van Krevelen diagrams can be used to describe the overall composition or evolution of organic mixtures (Van Krevelen, 1993; Nizkorodov et al., 2011; Nozière et al., 2015). Organic aerosol affected by biomass burning contained a significantly larger number of CHON formulae with $\mathrm{O} / \mathrm{C}<0.5$ and $\mathrm{H} / \mathrm{C}<1$ (Fig. 6a and b, area B) but a smaller number of formulae with $\mathrm{O} / \mathrm{C}<0.5$ and $\mathrm{H} / \mathrm{C}>1$ (Fig. 6a and b, area A). While molecules with $\mathrm{H} / \mathrm{C}$ ratios $(<1.0)$ and $\mathrm{O} / \mathrm{C}$ ratios $(<0.5)$ (area A in Fig. 3) are generally associated with aliphatic compounds, molecules with high $\mathrm{H} / \mathrm{C}$ ratios $(>1.5)$ and low $\mathrm{O} / \mathrm{C}$ ratios $(<0.5)$ typically belong to oxidised aromatic hydrocarbons (area B in Fig. 3) (Mazzoleni et al., 2010, 2012). Although the smaller number of nitro-aliphatic compounds in the samples affected by biomass burning requires further investigation, it is possible that they were oxidised in the polluted air by $\mathrm{NO}_{x}$ and $\mathrm{O}_{3}$ (Zahardis et al., 2008; Malloy et al., 2009), whose production is significantly enhanced during fire events (e.g. Galanter et al., 2000). The majority (up to $80 \%$ ) of the CHON molecules in the analysed samples have $\mathrm{O} / \mathrm{C}$ ratios $<0.7$ (Fig. 6). The relatively low oxygen content suggests that these molecules include decreased nitrogencontaining compounds (Zhao et al., 2013). Although biomass burning material type is expected to result in a different molecular composition, the presence of a large number of molecules with low $\mathrm{O} / \mathrm{C}$ ratio is consistent with the literature. For example, most of the CHON molecules in OA from wheat straw burning in K-Puszta in the Great Hungarian Plain of Hungary and biomass burning at Canadian rural sites (Saint Anicet, Quebec, and Canterbury, New Brunswick) had O / C ratios below 0.7 (Schmitt-Kopplin et al., 2010). In addition, the CHON molecules identified by LC/MS in biomass burning $\mathrm{OA}$ from Amazonia showed $\mathrm{O} / \mathrm{C}$ ratios below 0.7, i.e. 4-nitrocatechol $\left(\mathrm{C}_{6} \mathrm{H}_{5} \mathrm{NO}_{4} ; \mathrm{O} / \mathrm{C}=0.67\right)$, isomeric methyl-nitrocatechols $\left(\mathrm{C}_{7} \mathrm{H}_{7} \mathrm{NO}_{4} ; \mathrm{O} / \mathrm{C}=0.57\right)$, and isomeric dimethyl-nitrocatechols $\left(\mathrm{C}_{8} \mathrm{H}_{9} \mathrm{NO}_{4} ; \mathrm{O} / \mathrm{C}=0.50\right)$ (Claeys et al., 2012).

Figure 7 shows overlaid $\mathrm{OS}_{\mathrm{C}}$ plots for $\mathrm{OA}$ from the days with low, moderately high and high incidents of fires. During the days affected by high and moderately high number of fires, $\mathrm{OS}_{\mathrm{C}}$ was shifted towards a more oxidised state for the $\mathrm{CHO}$ molecules containing more than seven carbon atoms. The difference in $\mathrm{OS}_{\mathrm{C}}$ becomes even more pronounced with the increased number of carbons (e.g. $>7$ carbon atoms) in the detected molecular formulae. Interestingly, the affected ions with high $\mathrm{OS}_{\mathrm{C}}$ do not fall into the category of the BBOA (encircled area in Fig. 7) which are associated with primary particulate matter directly emitted into the atmosphere as defined in Kroll et al. (2011).

At a first glance, biomass burning seems to influence the number and intensity of the CHOS-containing formulae; however, the effect was much lower compared to that for the $\mathrm{CHO}$ and $\mathrm{CHON}$ molecules (see discussion above). A higher number of CHOS-containing molecules was observed in the sample (MP14-148) corresponding to the highest incident of fires (Fig. 8a). Interestingly, IEPOX-OS was found to be very abundant in the sample that experienced the highest incidents of fires (Fig. 8a). The significant IEPOXOS mass was previously observed during low-altitude flight campaigns in northern California and southern Oregon under high-NO conditions (> 500 pptv) (Liao et al., 2015). The authors explained this observation by the transport or formation of IEPOX from isoprene hydroxynitrate oxidation (Jacobs et al., 2014) and higher sulfate aerosol concentrations occurring during their sampling period (Nguyen et al., 2014). This explanation is also consistent with our results. The ion at $m / z 96.95987$ corresponding $\left[\mathrm{HSO}_{4}\right]^{-}$in UHR mass spectra of the sample MP14-148 was 3 times more abundant compared to that in the sample MP14-129, suggesting that particle acidity may be one of the reasons for the high abundance of the IEPOX-OS in this sample. Considering that the main sources of sulfate at $\mathrm{T} 3$ site are industrial pollution (e.g. power plants), natural and long-range sources, they could also be responsible for the high abundance of the sulfate and IEPOX-OS in the samples besides the overlapping biomass burning event. Noticeably, these samples contained not only 


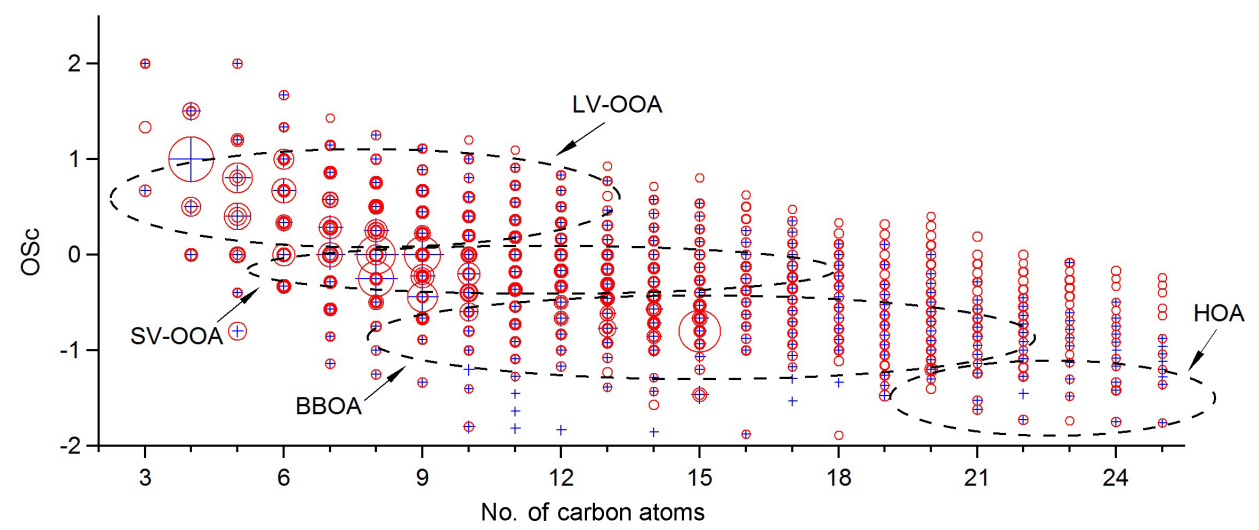

Figure 7. Overlaid carbon oxidation state $\left(\mathrm{OS}_{\mathrm{C}}\right)$ plots for $\mathrm{CHO}$ subgroups in the samples from the periods with low (blue markers) and very high (red markers) incidents of fires. The marker areas reflect relative ion abundance in the sample. The area marked as SV-OOA, LV-OOA, BBOA and HOA correspond to the molecules associated with semivolatile and low-volatility oxidised organic aerosol, biomass burning organic aerosol and hydrocarbon-like organic aerosol as outlined by Kroll et al. (2011).
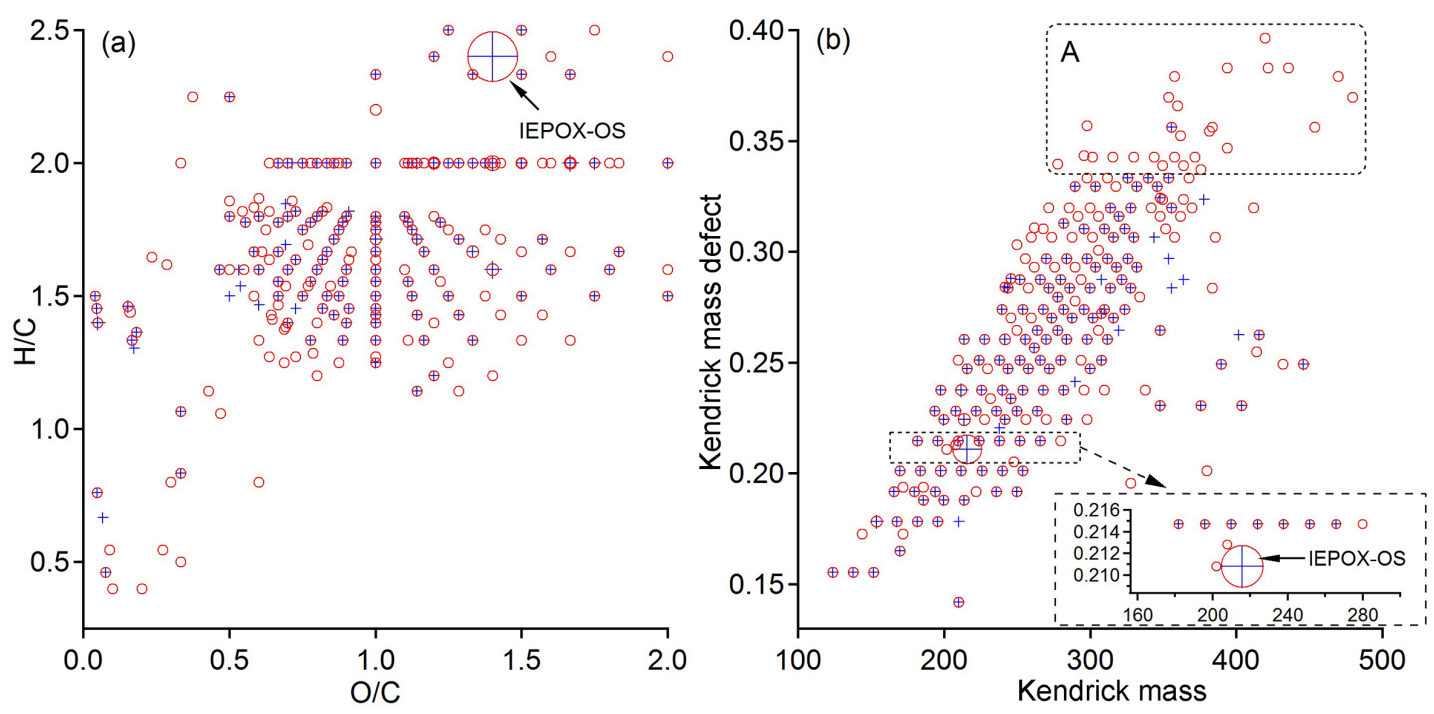

Figure 8. Overlaid Van Krevelen diagram (a) and Kendrick mass defect plot (b) for CHOS-containing formulae in the samples from the periods with low (blue markers) and very high incidents of fires (red markers). The marker areas reflect relative ion abundance in the sample. Red markers correspond to the ions from the period with the lowest incidents of fires. Note that IEPOX-OS is not a part of any homologous series in the sample with very low incident of fires and it has only one additional homologue in the sample that experienced very high incident of fires (see enlarged area of Fig. 8a). Area "A" in Kendrick mass defect plot shows formulae with KMD $>0.33$ that are mainly present in the sample with high incident of fires.

a larger number of oxygenated CHOS-containing molecules with $\mathrm{O} / \mathrm{C}>1.2$ but also molecules with $\mathrm{O} / \mathrm{C}<0.6$ and $\mathrm{H} / \mathrm{C}$ ranging from 0.4 to 2.2 . Recent laboratory and field studies indicated the presence of a large number of aromatic and aliphatic organosulfates and sulfonates in OA and linked them to anthropogenic precursors (Tao et al., 2014; Wang et al., 2016; Riva et al., 2015, 2016; Kuang et al., 2016). Riva et al. $(2015,2016)$ demonstrated formation of organosulfates and sulfonates in the laboratory smog chamber experiments from photooxidation of alkanes and PAHs, respectively. The authors indicated enhancement of organosulfates yields in the presence of acidified ammonium sulfate seed and suggested that these organosulfates are mainly formed through reactive uptake of gas-phase epoxides. It must be noted that the above-cited field studies are based on measurements in the Northern Hemisphere and thus organosulfate formation pathways and sources may differ from that of Amazonia.

KMD plots are a useful visualisation technique for identification of homologous series of compounds differing only by the number of a specific base unit (e.g. a $\mathrm{CH}_{2}$ group). Anthropogenically affected aerosol samples have longer homologous series of molecules containing CHOS subgroups 
(Fig. 8b). One of these longer series includes a second most abundant ion at $m / z 213.0075\left(\mathrm{C}_{5} \mathrm{H}_{10} \mathrm{O}_{7} \mathrm{~S}\right)$. The compound with a molecular formula of $\mathrm{C}_{5} \mathrm{H}_{10} \mathrm{O}_{7} \mathrm{~S}$ has been previously observed in the laboratory and field studies and attributed to isoprene-derived organosulfates (Surratt et al., 2008; Gómez-González, 2008; Kristensen and Glassius, 2011; Nguyen et al., 2014; Hettiyadura et al., 2015). This molecular formula could also be associated with organosulfates (e.g. isomeric 3-sulfooxy-2-hydroxypentanoic acid and 2-sulfooxy-3-hydroxypentanoic acid) formed from the green leaf volatiles 2-E-pentenal, 2-E-hexenal, and 3-hexenal (Shalamzari et al., 2016). The KMD plot (Fig. 8b) shows that OA from the anthropogenically affected samples contained an additional series of CHOS molecules with high $\mathrm{KMD}>0.33$ that were not present in the sample from the less polluted period. Most of these ions are highly oxygenated (containing $>10$ oxygens) and are likely to be associated with molecules produced through photochemical ageing reactions (Hildebrandt et al., 2010).

It is worth noting that, in most of the samples, IEPOX-OS was not a part of any homologous series in KMD plot (e.g. Fig. 8b). This observation confirms that atmospheric oxidation reactions resulting in the incorporation of $\mathrm{S}$ and $\mathrm{N}$ functional groups do not always conserve homologous series but could also lead to a wide range of possible reaction products (Rincón et al., 2012; Kourtchev et al., 2013).

\section{Conclusions}

In this study we applied direct infusion nanoESI UHRMS for the analysis of the organic fraction of $\mathrm{PM}_{2.5}$ samples collected IOP1 and IOP2 of GoAmazon2014/5 in central Amazonia, which is influenced by both background and polluted air masses. Up to 2100 elemental formulae were identified in the samples, with the largest number of formulae found during IOP2. The distribution of several tracer compounds along with the comprehensive mass spectral data evaluation methods (e.g. Kendrick mass defect, Van Krevelen diagrams, carbon oxidation state and aromaticity equivalent) applied to the large UHRMS datasets were used to identify various sources of organic aerosol components, including natural biogenic sources, biomass burning and anthropogenic emissions. The distinguishable homologous series in the KMD diagram contained nitrogen-containing series included NACs, e.g. nitrocatechols, nitrophenols, nitroguaiacols and nitrosalicylic acids derived from biomass burning material. Isoprene-derived IEPOX-OS was found to be the most dominant ion in most of the analysed samples and strongly followed the concentration trends of the gas-phase anthropogenic tracer benzene and $\mathrm{CO}$ (with biomass burning as the dominant tracer at the $\mathrm{T} 3$ site), supporting its mixed biomass burning-anthropogenic-biogenic origin. Van Krevelen, DBE and $X_{\mathrm{c}}$ distributions along with relatively low elemental $\mathrm{O} / \mathrm{C}$ and $\mathrm{H} / \mathrm{C}$ ratios indicated the presence of a large number of oxidised aromatic compounds in the samples. A significant number of $\mathrm{CHO}$-containing formulae in aerosol samples from IOP2 had a higher oxidation state compared to that from IOP1 and became even more important during the days with the highest incidents of fires. Although our results suggest that the studied site is significantly influenced by not only biogenic emissions and biomass burning but also anthropogenic emissions from the neighbouring urban activities, future work is needed to better understand the quantitative contributions of the various factors to the aerosol composition at the T3 site. The analysis of aerosol samples with higher sampling resolution or quantifying specific marker compounds and applying a receptor modelling techniques (Alves et al., 2015) would allow for separating these sources in more detail and would thus significantly improve understanding of the aerosol formation sources at the site.

\section{Data availability}

The data are available upon request.

\section{The Supplement related to this article is available online at doi:10.5194/acp-16-11899-2016-supplement.}

Acknowledgements. Research at the University of Cambridge was supported by ERC grant no. 279405. The authors would like to thank Jason Surratt (University of North Carolina) for providing a synthesised IEPOX-OS standard. $\mathrm{O}_{3}, \mathrm{CO}, \mathrm{NO}_{y}, \mathrm{RH}$ and rain data were obtained from the Atmospheric Radiation Measurement (ARM) Climate Research Facility, a U.S. Department of Energy (grant DE-SC0011122) Office of Science user facility sponsored by the Office of Biological and Environmental Research. We acknowledge the support from the Central Office of the Large Scale Biosphere Atmosphere Experiment in Amazonia (LBA), the Instituto Nacional de Pesquisas da Amazonia (INPA), and the Universidade do Estado do Amazonia (UEA). The work was conducted under 001030/2012-4 of the Brazilian National Council for Scientific and Technological Development (CNPq).

Edited by: J. Allan

Reviewed by: two anonymous referees

\section{References}

Alves, E. G., Jardine, K., Tota, J., Jardine, A., Yãnez-Serrano, A. M., Karl, T., Tavares, J., Nelson, B., Gu, D., Stavrakou, T., Martin, S., Artaxo, P., Manzi, A., and Guenther, A.: Seasonality of isoprenoid emissions from a primary rainforest in central Amazonia, Atmos. Chem. Phys., 16, 3903-3925, doi:10.5194/acp-163903-2016, 2016. 
Andreae, M. O. and Crutzen, P. J.: Atmospheric aerosols: Biogeochemical sources and role in atmospheric chemistry, Science, 276, 1052-1058, 1997.

Andreae, M. O., Acevedo, O. C., Araùjo, A., Artaxo, P., Barbosa, C. G. G., Barbosa, H. M. J., Brito, J., Carbone, S., Chi, X., Cintra, B. B. L., da Silva, N. F., Dias, N. L., Dias-Júnior, C. Q., Ditas, F., Ditz, R., Godoi, A. F. L., Godoi, R. H. M., Heimann, M., Hoffmann, T., Kesselmeier, J., Könemann, T., Krüger, M. L., Lavric, J. V., Manzi, A. O., Lopes, A. P., Martins, D. L., Mikhailov, E. F., Moran-Zuloaga, D., Nelson, B. W., Nölscher, A. C., Santos Nogueira, D., Piedade, M. T. F., Pöhlker, C., Pöschl, U., Quesada, C. A., Rizzo, L. V., Ro, C.-U., Ruckteschler, N., Sá, L. D. A., de Oliveira Sá, M., Sales, C. B., dos Santos, R. M. N., Saturno, J., Schöngart, J., Sörgel, M., de Souza, C. M., de Souza, R. A. F., Su, H., Targhetta, N., Tóta, J., Trebs, I., Trumbore, S., van Eijck, A., Walter, D., Wang, Z., Weber, B., Williams, J., Winderlich, J., Wittmann, F., Wolff, S., and Yáñez-Serrano, A. M.: The Amazon Tall Tower Observatory (ATTO): overview of pilot measurements on ecosystem ecology, meteorology, trace gases, and aerosols, Atmos. Chem. Phys., 15, 10723-10776, doi:10.5194/acp-15-10723-2015, 2015.

Ayres, B. R., Allen, H. M., Draper, D. C., Brown, S. S., Wild, R. J., Jimenez, J. L., Day, D. A., Campuzano-Jost, P., Hu, W., de Gouw, J., Koss, A., Cohen, R. C., Duffey, K. C., Romer, P., Baumann, K., Edgerton, E., Takahama, S., Thornton, J. A., Lee, B. H., Lopez-Hilfiker, F. D., Mohr, C., Wennberg, P. O., Nguyen, T. B., Teng, A., Goldstein, A. H., Olson, K., and Fry, J. L.: Organic nitrate aerosol formation via $\mathrm{NO}_{3}+$ biogenic volatile organic compounds in the southeastern United States, Atmos. Chem. Phys., 15, 13377-13392, doi:10.5194/acp-15-13377-2015, 2015.

Budisulistiorini, S. H., Li, X., Bairai, S. T., Renfro, J., Liu, Y., Liu, Y. J., McKinney, K. A., Martin, S. T., McNeill, V. F., Pye, H. O. T., Nenes, A., Neff, M. E., Stone, E. A., Mueller, S., Knote, C., Shaw, S. L., Zhang, Z., Gold, A., and Surratt, J. D.: Examining the effects of anthropogenic emissions on isoprenederived secondary organic aerosol formation during the 2013 Southern Oxidant and Aerosol Study (SOAS) at the Look Rock, Tennessee ground site, Atmos. Chem. Phys., 15, 8871-8888, doi:10.5194/acp-15-8871-2015, 2015.

Chen, Q., Farmer, D. K., Rizzo, L. V., Pauliquevis, T., Kuwata, M., Karl, T. G., Guenther, A., Allan, J. D., Coe, H., Andreae, M. O., Pöschl, U., Jimenez, J. L., Artaxo, P., and Martin, S. T.: Submicron particle mass concentrations and sources in the Amazonian wet season (AMAZE-08), Atmos. Chem. Phys., 15, 3687-3701, doi:10.5194/acp-15-3687-2015, 2015.

Claeys, M., Kourtchev, I., Pashynska, V., Vas, G., Vermeylen, R., Wang, W., Cafmeyer, J., Chi, X., Artaxo, P., Andreae, M. O., and Maenhaut, W.: Polar organic marker compounds in atmospheric aerosols during the LBA-SMOCC 2002 biomass burning experiment in Rondônia, Brazil: sources and source processes, time series, diel variations and size distributions, Atmos. Chem. Phys., 10, 9319-9331, doi:10.5194/acp-10-9319-2010, 2010.

Claeys, M., Vermeylen, R., Yasmeen, F., Gómez-González, Y., Chi, X., Maenhaut, W., Meszaros, T., and Salma, I.: Chemical characterisation of humic-like substances from urban, rural and tropical biomass burning environments using liquid chromatography with UV/vis photodiode array detection and electrospray ionisation mass spectrometry, Environ. Chem., 9, 273-284, doi:10.1071/EN11163, 2012.
Davies, T., Cullen, M. J. P., Malcolm, A. J., Mawson, M. H., Staniforth, A., White, A. A., and Wood, N.: A new dynamical core for the Met Office's global and regional modelling of the atmosphere, Q. J. Roy. Meteor. Soc., 131, 1759-1782, 2005.

Day, D. A., Liu, S., Russell, L. M., and Ziemann, P. J.: Organonitrate group concentrations in submicron particles with high nitrate and organic fractions in coastal southern California, Atmos. Environ., 44, 1970-1979, 2010.

de Gouw, J. A., Middlebrook, A. M., Warneke, C., Goldan, P. D., Kuster, W. C., Roberts, J. M., Fehsenfeld, F. C., Worsnop, D. R., Canagaratna, M. R., Pszenny, A. A. P., Keene, W. C., Marchewka, M., Bertman, S. B., and Bates, T. S.: Budget of organic carbon in a polluted atmosphere: Results from the New England Air Quality Study in 2002, J. Geophys. Res.-Atmos., 110, D16305, doi:10.1029/2004jd005623, 2005.

Dzepina, K., Mazzoleni, C., Fialho, P., China, S., Zhang, B., Owen, R. C., Helmig, D., Hueber, J., Kumar, S., Perlinger, J. A., Kramer, L. J., Dziobak, M. P., Ampadu, M. T., Olsen, S., Wuebbles, D. J., and Mazzoleni, L. R.: Molecular characterization of free tropospheric aerosol collected at the Pico Mountain Observatory: a case study with a long-range transported biomass burning plume, Atmos. Chem. Phys., 15, 5047-5068, 2015.

Friedli, H. R., Atlas, E., Stroud, V. R., Giovanni, L., Campos, T., and Radke, L. F.: Volatile organic trace gases emitted from North American wildfires, Global Biogeochem. Cy., 15, 435452, 2001.

Fry, J. L., Draper, D. C., Barsanti, K. C., Smith, J. N., Ortega, J., Winkler, P. M., Lawler, M. J., Brown, S. S., Edwards, P. M., Cohen, R. C., and Lee, L.: Secondary organic aerosol formation and organic nitrate yield from $\mathrm{NO}_{3}$ oxidation of biogenic hydrocarbons, Environ. Sci. Technol., 48, 11944-11953, 2014.

Galanter, M., Levy II, H., and Carmichael, G. R.: Impacts of biomass burning on tropospheric $\mathrm{CO}, \mathrm{NO}_{x}$, and $\mathrm{O}_{3}$, J. Geophys. Res., 105, 6633-6653, 2000.

Goldstein, A. H. and Galbally, I. E.: Known and unexplored organic carbon constituents in the Earth's atmosphere, Environ. Sci. Technol., 41, 1514-1521, 2007.

Goldstein, A. H., Koven, C. D., Heald, C. L., and Fung, I. Y.: Biogenic carbon and anthropogenic pollutants combine to form a cooling haze over the southeastern United States, P. Natl. Acad. Sci. USA, 106, 8835-8840, 2009.

Gómez-González, Y., Surratt, J. D., Cuyckens, F., Szmigielski, R., Vermeylen, R., Jaoui, M., Lewandowski, M., Offenberg, J. H., Kleindienst, T. E., Edney, E. O., Blockhuys, F., Van Alsenoy, C., Maenhaut, W., and Claeys, M.: Characterization of organosufates from the photooxidation of isoprene and unsaturated fatty acids in ambient aerosol using liquid chromatography/(-) electrospray ionization mass spectrometry, J. Mass Spectrom., 43, 371-382, 2008.

Graus, M., Müller, M., and Hansel, A.: High Resolution PTR-TOF: Quantification and Formula Confirmation of VOC in Real Time, J. Am. Soc. Mass Spectrom., 21, 1037-1044, 2010.

Greenberg, J., Guenther, A., Petron, G., Wiedinmyer, C., Vega, O., Gatti, L. V., Tota, J., and Fisch, G.: Biogenic VOC emissions from forested Amazonian landscapes, Global Change Biol., 10, 651-662, 2004.

Hallquist, M., Wenger, J. C., Baltensperger, U., Rudich, Y., Simpson, D., Claeys, M., Dommen, J., Donahue, N. M., George, C., Goldstein, A. H., Hamilton, J. F., Herrmann, H., Hoff- 
mann, T., Iinuma, Y., Jang, M., Jenkin, M. E., Jimenez, J. L., Kiendler-Scharr, A., Maenhaut, W., McFiggans, G., Mentel, Th. F., Monod, A., Prévôt, A. S. H., Seinfeld, J. H., Surratt, J. D., Szmigielski, R., and Wildt, J.: The formation, properties and impact of secondary organic aerosol: current and emerging issues, Atmos. Chem. Phys., 9, 5155-5236, doi:10.5194/acp-9-51552009, 2009.

Haywood, J. and Boucher, O.: Estimates of the direct and indirect radiative forcing due to tropospheric aerosols: A review, Rev. Geophys., 38, 513-543, 2000.

Hettiyadura, A. P. S., Stone, E. A., Kundu, S., Baker, Z., Geddes, E., Richards, K., and Humphry, T.: Determination of atmospheric organosulfates using HILIC chromatography with MS detection, Atmos. Meas. Tech., 8, 2347-2358, doi:10.5194/amt8-2347-2015, 2015.

Hildebrandt, L., Engelhart, G. J., Mohr, C., Kostenidou, E., Lanz, V. A., Bougiatioti, A., DeCarlo, P. F., Prevot, A. S. H., Baltensperger, U., Mihalopoulos, N., Donahue, N. M., and Pandis, S. N.: Aged organic aerosol in the Eastern Mediterranean: the Finokalia Aerosol Measurement Experiment - 2008, Atmos. Chem. Phys., 10, 4167-4186, doi:10.5194/acp-10-4167-2010, 2010.

Hoyle, C. R., Boy, M., Donahue, N. M., Fry, J. L., Glasius, M., Guenther, A., Hallar, A. G., Huff Hartz, K., Petters, M. D., Petäjä, T., Rosenoern, T., and Sullivan, A. P.: A review of the anthropogenic influence on biogenic secondary organic aerosol, Atmos. Chem. Phys., 11, 321-343, doi:10.5194/acp-11-321-2011, 2011.

Hsieh, C. C., Chang, K. H., and Kao, Y. S.: Estimating theozone formation potential of volatile aromatic compoundsin vehicles tunnels, Chemosphere, 39, 1433-1444, 1999.

Iinuma, Y., Boge, O., Grafe, R., and Herrmann, H.: MethylNitrocatechols: atmospheric tracer compounds for biomass burning secondary organic aerosols, Environ. Sci. Technol., 44, 8453-8459, 2010.

Jacobs, M. I., Burke, W. J., and Elrod, M. J.: Kinetics of the reactions of isoprene-derived hydroxynitrates: gas phase epoxide formation and solution phase hydrolysis, Atmos. Chem. Phys., 14, 8933-8946, doi:10.5194/acp-14-8933-2014, 2014.

Jacobson, M. Z.: Isolating nitrated and aromatic aerosols and nitrated aromatic gases as sources of ultraviolet light absorption, J. Geophys. Res.-Atmos., 104, 3527-3542, 1999.

Kahnt, A., Behrouzi, S., Vermeylen, R., Sa Shalamzari, M., Vercauteren, J., Roekens, E., Claeys, M., and Maenhaut, W.: One year study of nitro-organic compounds and their relation to wood burning in $\mathrm{PM}_{10}$ aerosol from a rural site in Belgium, Atmos. Environ., 81, 561-568, 2013.

Keller, M., Bustamante, M., Gash, J., and Dias, P.: Amazonia and Global Change, Vol. 186, American Geophysical Union, Wiley, Washington, DC, 2009.

Kendrick, E.: A Mass Scale Based on $\mathrm{CH}_{2}=14.0000$ for High Resolution Mass Spectrometry of Organic Compounds, Anal. Chem., 35, 2146-2154, 1963.

Kitanovski, Z., Grgiìc, I., Vermeylen, R., Claeys, M., and Maenhaut, W.: Liquid chromatography tandem mass spectrometry method for characterization of monoaromatic nitro-compounds in atmospheric particulate matter, J. Chromatogr. A, 1268, 35-43, 2012a.

Kitanovski, Z., Grgic, I., Yasmeen, F., Claeys, M., and Cusak, A.: Development of a liquid chromatographic method based on ultraviolet-visible and electrospray ionization mass spectromet- ric detection for the identification of nitrocatechols and related tracers in biomass burning atmospheric organic aerosol, Rapid Commun. Mass Sp., 26, 793-804, 2012b.

Kleinman, L., Kuang, C., Sedlacek, A., Senum, G., Springston, S., Wang, J., Zhang, Q., Jayne, J., Fast, J., Hubbe, J., Shilling, J., and Zaveri, R.: What do correlations tell us about anthropogenicbiogenic interactions and SOA formation in the Sacramento plume during CARES?, Atmos. Chem. Phys., 16, 1729-1746, doi:10.5194/acp-16-1729-2016, 2016.

Kourtchev, I., Hellebust, S., Bell, J. M., O’Connor, I. P., Healy, R. M., Allanic, A., Healy, D., Wenger, J. C., and Sodeau, J. R.: The use of polar organic compounds to estimate the contribution of domestic solid fuel combustion and biogenic sources to ambient levels of organic carbon and $\mathrm{PM}_{2.5}$ in Cork Harbour, Ireland, Sci. Total Environ., 409, 2143-2155, 2011.

Kourtchev, I., Fuller, S., Aalto, J., Ruuskanen, T. M., McLeod, M. W., Maenhaut, W., Jones, R., Kulmala, M., and Kalberer, M.: Molecular composition of boreal forest aerosol from Hyytiälä, Finland, using ultrahigh resolution mass spectrometry, Environ. Sci. Technol., 47, 4069-4079, 2013.

Kourtchev, I., O’Connor, I. P., Giorio, C., Fuller, S., Kristensen, K., Maenhaut, W., Wenger, J. C., Sodeau, J. R., Glasius, M., and Kalberer, M.: Effects of anthropogenic emissions on the molecular composition of urban organic aerosols: an ultrahigh resolution mass spectrometry study, Atmos. Environ., 89, 525-532, 2014.

Kourtchev, I., Doussin, J.-F., Giorio, C., Mahon, B., Wilson, E. M., Maurin, N., Pangui, E., Venables, D. S., Wenger, J. C., and Kalberer, M.: Molecular composition of fresh and aged secondary organic aerosol from a mixture of biogenic volatile compounds: a high-resolution mass spectrometry study, Atmos. Chem. Phys., 15, 5683-5695, doi:10.5194/acp-15-5683-2015, 2015.

Kristensen, K. and Glasius, M.: Organosulfates and oxidation products from biogenic hydrocarbons in fine aerosols from a forest in North West Europe during spring, Atmos. Environ., 45, 45464556, 2011.

Kroll, J. H., Donahue, N. M., Jimenez, J. L., Kessler, S. H., Canagaratna, M. R., Wilson, K. R., Altieri, K. E., Mazzoleni, L. R., Wozniak, A. S., Bluhm, H., Mysak, E. R., Smith, J. D., Kolb, C. E., and Worsnop, D. R.: Carbon oxidation state as a metric for describing the chemistry of atmospheric organic aerosol, Nat. Chem. Biol., 3, 133-139, 2011.

Kuang, B. Y., Lin, P., Hub, M., and Yu, J. Z.: Aerosol size distribution characteristics of organosulfates in the Pearl River Delta region, China, Atmos. Environ., 130, 23-35, 2016.

Laskin, A., Laskin, J., and Nizkorodov, S. A.: Chemistry of Atmospheric Brown Carbon, Chem. Rev., 115, 4335-4382, 2015.

Liao, J., Froyd, K. D., Murphy, D. M., Keutsch, F. N., Yu, G., Wennberg, P. O., St. Clair, J. M., Crounse, J. D., Wisthaler, A., Mikoviny, T., Jimenez, J. L., Campuzano-Jost, P., Day, D. A., Hu, W., Ryerson, T. B., Pollack, I. B., Peischl, J., Anderson, B. E., Ziemba, L. D., Blake, D. R., Meinardi, S., and Diskin, G.: Airborne measurements of organosulfates over the continental U.S., J. Geophys. Res., 120, 2990-3005, doi:10.1002/2014JD022378, 2015.

Lin, Y.-H., Zhang, Z. F., Docherty, K. S., Zhang, H. F., Budisulistiorini, S. H., Rubitschun, C. L., Shaw, S. L., Knipping, E. M., Edgerton, E. S., Kleindienst, T. E., Gold, A., and Surratt, J. D.: Isoprene Epoxydiols as Precursors to Secondary Organic Aerosol 
Formation: Acid-Catalyzed Reactive Uptake Studies with Authentic Compounds, Environ. Sci. Technol., 46, 250-258, 2012.

Lin, Y.-H., Knipping, E. M., Edgerton, E. S., Shaw, S. L., and Surratt, J. D.: Investigating the influences of $\mathrm{SO}_{2}$ and $\mathrm{NH}_{3}$ levels on isoprene-derived secondary organic aerosol formation using conditional sampling approaches, Atmos. Chem. Phys., 13, 84578470, doi:10.5194/acp-13-8457-2013, 2013.

Liu, S., Shilling, J. E., Song, C., Hiranuma, N., Zaveri, R. A., and Russell, L. M.: Hydrolysis of Organonitrate Functional Groups in Aerosol Particles, Aerosol Sci. Tech., 46, 1359-1369, doi:10.1080/02786826.2012.716175, 2012.

Lu, J. W., Flores, J. M., Lavi, A., Abo-Riziq, A., and Rudich, Y.: Changes in the optical properties of benzo[a]pyrene-coated aerosols upon heterogeneous reactions with $\mathrm{NO}_{2}$ and $\mathrm{NO}_{3}$, Phys. Chem. Chem. Phys., 13, 6484-6492, 2011.

Malloy, Q. G. J., Li Qi, Warren, B., Cocker III, D. R., Erupe, M. E., and Silva, P. J.: Secondary organic aerosol formation from primary aliphatic amines with $\mathrm{NO}_{3}$ radical, Atmos. Chem. Phys., 9, 2051-2060, doi:10.5194/acp-9-2051-2009, 2009.

Martin, S. T., Andreae, M. O., Artaxo, P., Baumgardner, D., Chen, Q., Goldstein, A. H., Guenther, A., Heald, C. L., Mayol-Bracero, O. L., McMurry, P. H., Pauliquevis, T., Pöschl, U., Prather, K. A., Roberts, G. C., Saleska, S. R., Silva Dias, M. A., Spracklen, D. V., Swietlicki, E., and Trebs, I.: Sources and properties of Amazonian aerosol particles, Rev. Geophys., 48, RG2002, doi:10.1029/2008RG000280, 2010.

Martin, S. T., Artaxo, P., Machado, L. A. T., Manzi, A. O., Souza, R. A. F., Schumacher, C., Wang, J., Andreae, M. O., Barbosa, H. M. J., Fan, J., Fisch, G., Goldstein, A. H., Guenther, A., Jimenez, J. L., Pöschl, U., Silva Dias, M. A., Smith, J. N., and Wendisch, M.: Introduction: Observations and Modeling of the Green Ocean Amazon (GoAmazon2014/5), Atmos. Chem. Phys., 16, 47854797, doi:10.5194/acp-16-4785-2016, 2016.

Maryon, R. H., Smith, F. B., Conway, B. J., and Goddard, D. M.: The U.K. nuclear accident model, Prog. Nucl. Energy, 26, 85104, 1991.

Mazzoleni, L. R., Ehrmann, B. M., Shen, X., Marshall, A. G., and Collett Jr., J. L.: Water-soluble atmospheric organic matter in fog: exact masses and chemical formula identification by ultrahighresolution Fourier transform ion cyclotron resonance mass spectrometry, Environ. Sci. Technol., 44, 3690-3697, 2010.

Mazzoleni, L. R., Saranjampour, P., Dalbec, M. M., Samburova, V., Hallar, A. G., Zielinska, B., Lowenthal, D., and Kohl, S.: Identification of water-soluble organic carbon in nonurban aerosols using ultrahigh-resolution FT-ICR mass spectrometry: organic anions, Environ. Chem., 9, 285-297, 2012.

Misztal, P. K., Hewitt, C. N., Wildt, J., Blande, J. D., Eller, A. S. D., Fares, S., Gentner, D. R., Gilman, J. B., Graus, M., Greenberg, J., Guenther, A. B., Hansel, A., Harley, P., Huang, M., Jardine, K., Karl, T., Kaser, L., Keutsch, F. N., Kiendler-Scharr, A., Kleist, E., Lerner, B. M., Li, T., Mak, J., Nölscher, A. C., Schnitzhofer, R., Sinha, V., Thornton, B., Warneke, C., Wegener, F., Werner, C., Williams, J., Worton, D. R., Yassaa, N., and Goldstein, A. H.: Atmospheric benzenoid emissions from plants rival those from fossil fuels, Sci. Rep., 5, 12064, doi:10.1038/srep12064, 2015.

Müller, M., Mikoviny, T., Jud, W., D’Anna, B., and Wisthaler, A.: A New Software Tool for the Analysis of High Resolution PTR-TOF Mass Spectra, Chemometr. Intell. Lab., 127, 158-165, 2013.
Nguyen, Q. T., Christensen, M. K., Cozzi, F., Zare, A., Hansen, A. M. K., Kristensen, K., Tulinius, T. E., Madsen, H. H., Christensen, J. H., Brandt, J., Massling, A., Nøjgaard, J. K., and Glasius, M.: Understanding the anthropogenic influence on formation of biogenic secondary organic aerosols in Denmark via analysis of organosulfates and related oxidation products, Atmos. Chem. Phys., 14, 8961-8981, doi:10.5194/acp-14-8961-2014, 2014.

Nizkorodov, S. A., Laskin, J., and Laskin, A.: Molecular chemistry of organic aerosols through the application of high resolution mass spectrometry, Phys. Chem. Chem. Phys., 13, 3612-3629, 2011.

Nozière, B., Kalberer, M., Claeys, M., Allan, J., D’Anna, B., Decesari, S., Finessi, E., Glasius, M., Grgic, I., Hamilton, J. F., Hoffmann, T., Iinuma, Y., Jaoui, M., Kahnt, A., Kampf, C. J., Kourtchev, I., Maenhaut, W., Marsden, N., Saarikoski, S., Schnelle-Kreis, J., Surratt, J., Szidat, S., Szmigielski, R., and Wisthaler, S.: The molecular identification of organic compounds in the atmosphere: state of the art and challenges, Chem. Rev., 115, 3919-3983, 2015.

Oss, M., Kruve, A., Herodes, K., and Leito, I.: Electrospray ionization efficiency scale of organic compounds, Anal. Chem., 82, 2865-2872, 2010.

Pashynska, V., Vermeylen, R., Vas, G., Maenhaut, W., and Claeys, M.: Development of a gas chromatographic/ion trap mass spectrometric method for the determination of levoglucosan and saccharidic compounds in atmospheric aerosols. Application to urban aerosols, J. Mass Spectrom., 37, 1249-1257, 2002.

Pöschl, U., Martin, S. T., Sinha, B., Chen, Q., Gunthe, S. S., Huffman, J. A., Borrmann, S., Farmer, D. K., Garland, R. M., Helas, G., Jimenez, J. L., King, S. M., Manzi, A., Mikhailov, E., Pauliquevis, T., Petters, M. D., Prenni, A. J., Roldin, P., Rose, D., Schneider, J., Su, H., Zorn, S. R., Artaxo, P., and Andreae, M. O.: Rainforest aerosols as biogenic nuclei of clouds and precipitation in the Amazon, Science, 429, 1513-1516, 2010.

Pye, H. O. T., Pinder, R. W., Piletic, I. R., Xie, Y., Capps, S. L., Lin, Y.-H., Surratt, J. D., Zhang, Z., Gold, A., Luecken, D. J., Hutzell, W. T., Jaoui, M., Offenberg, J. H., Kleindienst, T. E., Lewandowski, M., and Edney, E. O.: Epoxide pathways improve model predictions of isoprene markers and reveal key role of acidity in aerosol formation, Environ. Sci. Technol., 47, 1105611064, 2013.

Rasmussen, R. A. and Khalil, M. A. K.: Isoprene over the Amazon Basin. J. Geophys. Res., 93, 1417-1427, doi:10.1029/JD093iD02p01417JD093iD02p01417, 1988.

Reemtsma, T.: Determination of molecular formulas of natural organic matter molecules by (ultra-) high-resolution mass spectrometry status and needs, J. Chromatogr. A, 1216, 3687-3701, 2009.

Rincón, A. G., Calvo, A. I., Dietzel, M., and Kalberer, M.: Seasonal differences of urban organic aerosol composition: an ultra-high resolution mass spectrometry study, Environ. Chem., 9, 298-319, 2012.

Riva, M., Tomaz, S., Cui, T., Lin, Y.-H., Perraudin, E., Gold, A., Stone, E. A., Villenave, E., and Surratt, J. D.: Evidence for an unrecognized secondary anthropogenic source of organosulfates and sulfonates: gas-phase oxidation of polycyclic aromatic hydrocarbons in the presence of sulfate aerosol, Environ. Sci. Technol., 49, 6654-6664, 2015. 
Riva, M., Da Silva Barbosa, T., Lin, Y.-H., Stone, E. A., Gold, A., and Surratt, J. D.: Chemical characterization of organosulfates in secondary organic aerosol derived from the photooxidation of alkanes, Atmos. Chem. Phys., 16, 11001-11018, doi:10.5194/acp-16-11001-2016, 2016.

Roberts, J. M.: The atmospheric chemistry of organic nitrates, Atmos. Environ., 24, 243-287, 1990.

Ryall, D. B. and Maryon, R. H.: Validation of the UK Met Office's NAME model against the ETEX dataset, Atmos. Environ., 32, 4265-4276, 1998.

Schmitt-Kopplin, P., Gelencsìer, A., Dabek-Zlotorzynska, E., Kiss, G., Hertkorn, N., Harir, M., Hong, Y., and Gebefügi, I.: Analysis of the unresolved organic fraction in atmospheric aerosols with ultrahigh-resolution mass spectrometry and nuclear magnetic resonance spectroscopy: Organosulfates as photochemical smog constituents, Anal. Chem., 82, 8017-8026, 2010.

Seco, R., Peñuelas, J., Filella, I., Llusia, J., Schallhart, S., Metzger, A., Müller, M., and Hansel, A.: Volatile organic compounds in the western Mediterranean basin: urban and rural winter measurements during the DAURE campaign, Atmos. Chem. Phys., 13, 4291-4306, doi:10.5194/acp-13-4291-2013, 2013.

Shalamzari, M. S., Vermeylen, R., Blockhuys, F., Kleindienst, T. E., Lewandowski, M., Szmigielski, R., Rudzinski, K. J., Spólnik, G., Danikiewicz, W., Maenhaut, W., and Claeys, M.: Characterization of polar organosulfates in secondary organic aerosol from the unsaturated aldehydes 2-E-pentenal, 2-E-hexenal, and 3-Zhexenal, Atmos. Chem. Phys., 16, 7135-7148, doi:10.5194/acp16-7135-2016, 2016.

Simoneit, B. R. T., Schauer, J. J., Nolte, C. G., Oros, D. R., Elias, V. O., Fraser, M. P., Rogge, W. F. and Cass, G. R.: Levoglucosan, a tracer for cellulose in biomass burning and atmospheric particles, Atmos. Environ., 33, 173-182, 1999.

Sleighter, R. L., Chen, H., Wozniak, A. S., Willoughby, A. S., Caricasole, P., and Hatcher, P. G.: Establishing a measure of reproducibility of ultrahigh resolution mass spectra for complex mixtures of natural organic matter, Anal. Chem., 84, 9184-9191, 2012.

Song, C., Gyawali, M., Zaveri, R. A., Shilling, J. E., and Arnott, W. P.: Light absorption by secondary organic aerosol from $\alpha$-pinene: Effects of oxidants, seed aerosol acidity, and relative humidity, J. Geophys. Res., 118, 11741-11749, doi:10.1002/jgrd.50767, 2013.

Surratt, J. D., Lewandowski, M., Offenberg, J. H., Jaoui, M., Kleindienst, T. E., Edney, E. O., and Seinfeld, J. H.: Effect of acidity on secondary organic aerosol formation from isoprene, Environ. Sci. Technol., 41, 5363-5369, 2007.

Surratt, J. D., Gomez-Gonzalez, Y., Chan, A. W. H., Vermeylen, R., Shahgholi, M., Kleindienst, T. E., Edney, E. O., Offenberg, J. H., Lewandowski, M., Jaoui, M., Maenhaut, W., Claeys, M., Flagan, R. C., and Seinfeld, J. H.: Organosulfate formation in biogenic secondary organic aerosol, J. Phys. Chem. A, 112, 8345-8378, 2008.
Surratt, J. D., Chan, A. W. H., Eddingsaas, N. C., Chan, M. N., Loza, C. L., Kwan, A. J., Hersey, S. P., Flagan, R. C., Wennberg, P. O., and Seinfeld, J. H.: Reactive intermediates revealed in secondary organic aerosol formation from isoprene, P. Natl. Acad. Sci. USA, 107, 6640-6645, 2010.

Szmigielski, R., Surratt, J. D., Gomez-Gonzalez, Y., Van der Veken, P., Kourtchev, I., Vermeylen, R., Blockhuys, F., Jaoui, M., Kleindienst, T. E., Lewandowski, M., Offenberg, J. H., Edney, E. O., Seinfeld, J. H., Maenhaut, W., and Claeys, M.: 3-methyl1,2,3-butanetricarboxylic acid: An atmospheric tracer for terpene secondary organic aerosol, Geophys. Res. Lett., 34, L24811, doi:10.1029/2007GL031338, 2007.

Tao, S., Lu, X., Levac, N., Bateman, A. P., Nguyen, T. B., Bones, D. L., Nizkorodov, S. A., Laskin, J., Laskin, A., and Yang, X.: Molecular characterization of organosulfates in organic aerosols from Shanghai and Los Angeles urban areas by nanospraydesorption electrospray ionization high-resolution mass spectrometry, Environ. Sci. Technol., 48, 10993-11001, 2014.

Tong, H., Kourtchev, I., Pant, P., Keyte, I., O’Connor, I., Wenger, J., Pope, F. D., Harrison, R. M., and Kalberer, M.: FDATMOS16 Molecular Composition of Organic Aerosols at Urban Background and Road Tunnel sites using Ultra-high Resolution Mass Spectrometry, Faraday Discuss., 189, 51-68, doi:10.1039/C5FD00206K, 2016.

Van Krevelen, D. W.: Coal: Typology-Physics-ChemistryConstitution, Elsevier, Science, Amsterdam, The Netherlands, 1993.

Wang, X. K., Rossignol, S., Ma, Y., Yao, L., Wang, M. Y., Chen, J. M., George, C., and Wang, L.: Molecular characterization of atmospheric particulate organosulfates in three megacities at the middle and lower reaches of the Yangtze River, Atmos. Chem. Phys., 16, 2285-2298, doi:10.5194/acp-16-2285-2016, 2016.

Wozniak, A. S., Bauer, J. E., Sleighter, R. L., Dickhut, R. M., and Hatcher, P. G.: Technical Note: Molecular characterization of aerosol-derived water soluble organic carbon using ultrahigh resolution electrospray ionization Fourier transform ion cyclotron resonance mass spectrometry, Atmos. Chem. Phys., 8, 50995111, doi:10.5194/acp-8-5099-2008, 2008.

Yassine, M. M., Harir, M., Dabek-Zlotorzynska, E., and SchmittKopplin, P.: Structural characterization of organic aerosol using Fourier transform ion cyclotron resonance mass spectrometry: aromaticity equivalent approach, Rapid Commun. Mass Spectrom., 28, 2445-2454, 2014.

Zahardis, J., Geddes, S., and Petrucci, G. A.: The ozonolysis of primary aliphatic amines in fine particles, Atmos. Chem. Phys., 8, 1181-1194, doi:10.5194/acp-8-1181-2008, 2008.

Zhao, Y., Hallar, A. G., and Mazzoleni, L. R.: Atmospheric organic matter in clouds: exact masses and molecular formula identification using ultrahigh-resolution FT-ICR mass spectrometry, Atmos. Chem. Phys., 13, 12343-12362, doi:10.5194/acp13-12343-2013, 2013. 